\title{
Structure and electrical properties of a one-dimensional polymeric silver thiosaccharinate complex with argentophilic interactions
}

\section{Mariana Dennehy, Pilar Amo-Ochoa, Eleonora Freire, Sebastián Suárez, Emilia Halac and Ricardo Baggio}

Acta Cryst. (2018). C74, 186-193

\section{H IUCr Journals CRYSTALLOGRAPHY JOURNALS ONLINE}

Copyright (C) International Union of Crystallography

Author(s) of this paper may load this reprint on their own web site or institutional repository provided that this cover page is retained. Republication of this article or its storage in electronic databases other than as specified above is not permitted without prior permission in writing from the IUCr.

For further information see http://journals.iucr.org/services/authorrights.html 


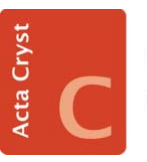

STRUCTURAL

CHEMISTRY

ISSN 2053-2296

Received 18 October 2017

Accepted 2 January 2018

Edited by G. P. A. Yap, University of Delaware, USA

₹ Member of Consejo Nacional de Investigaciones Científicas y Técnicas, Conicet.

Keywords: silver(I) polymeric structure; low conductivity semiconductor; one-dimensional coordination polymer; argentophilic interaction; electrical properties; crystal structure.

CCDC reference: 1814355

Supporting information: this article has supporting information at journals.iucr.org/c

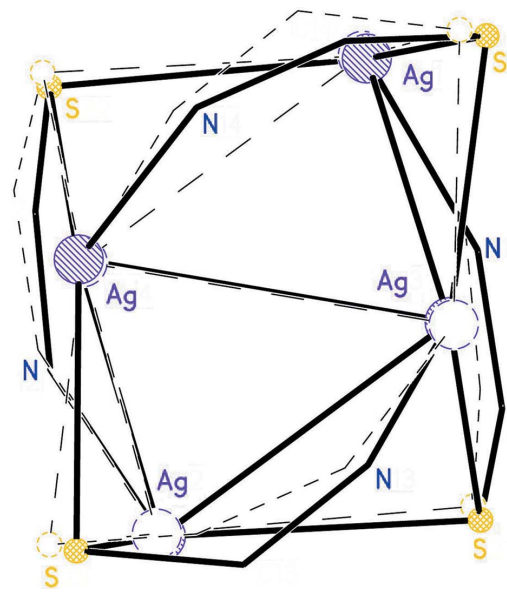

(C) 2018 International Union of Crystallography

\section{Structure and electrical properties of a one-dimen- sional polymeric silver thiosaccharinate complex with argentophilic interactions}

\author{
Mariana Dennehy, ${ }^{\mathrm{a} *}$ Pilar Amo-Ochoa, ${ }^{\mathrm{b}}$ Eleonora Freire,,${ }^{\mathrm{c}, \mathrm{d}} \neq$ Sebastián Suárez, ${ }^{{ }^{e}}$ \\ Emilia Halac ${ }^{\mathrm{c}, \mathrm{d}}$ and Ricardo Baggio ${ }^{\mathrm{c} *}$
}

\begin{abstract}
àDepartamento de Química (INQUISUR), Universidad Nacional del Sur, Bahía Blanca, Argentina, 'b Departamento de Química Inorgánica, Facultad de Ciencias, Universidad Autónoma de Madrid, Madrid, Spain, ' Gerencia de Investigación y Aplicaciones, Centro Atómico Constituyentes, Comisión Nacional de Energía Atómica, Buenos Aires, Argentina, dEscuela de Ciencia y Tecnología, Universidad Nacional General San Martín, Buenos Aires, Argentina, and e Departamento de Química Inorgánica, Analítica y Química, Física/INQUIMAE-CONICET, Facultad de Ciencias Exactas y Naturales, Universidad de Buenos Aires, Buenos Aires, Argentina. *Correspondence e-mail: mdennehy@uns.edu.ar, baggio@tandar.cnea.gov.ar
\end{abstract}

Among the potential applications of coordination polymers, electrical conductivity ranks high in technological interest. We report the synthesis, crystal structure and spectroscopic analysis of an $\mathrm{Ag}^{\mathrm{I}}$-thiosaccharinate one-dimensional coordination polymer \{systematic name: catena-poly[[[aquatetrakis $\left(\mu_{3^{-}}\right.$ 1,1-dioxo-1,2-benzisothiazole-3-thiolato- $\left.\kappa^{3} N: S^{3}: S^{3}\right)$ tetrasilver(I)]- $\mu_{2}-4,4^{\prime}$-(propane1,3-diyl)dipyridine- $\left.\kappa^{2} N: N^{\prime}\right]$ dimethyl sulfoxide hemisolvate $\left.]\right\},\left\{\left[\mathrm{Ag}_{4}\left(\mathrm{C}_{7} \mathrm{H}_{4} \mathrm{NO}_{2} \mathrm{~S}_{2}\right)_{4^{-}}\right.\right.$ $\left.\left.\left(\mathrm{C}_{13} \mathrm{H}_{14} \mathrm{~N}_{2}\right)\left(\mathrm{H}_{2} \mathrm{O}\right)\right] \cdot 0.5 \mathrm{C}_{2} \mathrm{H}_{6} \mathrm{OS}\right\}_{n}$, with the 4,4'-(propane-1,3-diyl)dipyridine ligand acting as a spacer. A relevant feature of the structure is the presence of an unusually short $\mathrm{Ag} \cdots \mathrm{Ag}$ distance of 2.8306 (9) $\AA$, well within the range of argentophilic interactions, confirmed experimentally as such by a Raman study on the low-frequency spectrum, and corroborated theoretically by an Atoms in Molecules (AIM) analysis of the calculated electron density. Electrical conductivity measurements show that this complex can act as a semiconductor with moderate conductivity.

\section{Introduction}

The synthesis of coordination compounds with $\mathrm{Ag}^{\mathrm{I}}$ metal centres results in a large panoply of different structural motifs, even when using similar starting coligands, due to the extreme coordination versatility of the $\mathrm{Ag}^{\mathrm{I}}$ cation. In the case of silver thiosaccharinates, this characteristic has been widely tested (Burrow et al., 2016).

In addition, coordination polymers are currently a trending topic due to the potential applications of their varied properties, among which electrical conductivity (EC) ranks high in technological interest (Givaja et al., 2012).

In this work, we present the synthesis, structural characterization and electrical conductivity (EC) measurements of a new coordination polymer, denoted $\left\{\left[\mathrm{Ag}_{4}(\mathrm{tsac})_{4}(\mathrm{tmdp})\right.\right.$ $\left.\left(\mathrm{H}_{2} \mathrm{O}\right)\right] \cdot 0.5 \mathrm{DMSO}_{n}$, (I), where tsac is the thiosaccharinate anion, tmdp is $4,4^{\prime}$-(propane-1,3-diyl)dipyridine and DMSO is dimethyl sulfoxide.

In addition, the $\mathrm{EC}$ of (I) is compared with those of some related polymeric silver thiosaccharinates, viz. $\left[\mathrm{Ag}_{2}(\mathrm{tsac})_{2^{-}}\right.$ (4,4'-bipyridine) $\left.)_{1.5}\right]_{n}$, (II) (Dennehy et al., 2016), and [Ag(tsac)(4-MeOpy) $]_{n}$ (4-MeOPy is 4 methoxypyridine), (III) (Dennehy et al., 2010), with the aim of explaining eventual EC differences in terms of their structural variations. 


\section{Experimental}

\subsection{Synthesis and crystallization}

Compound (I) was synthesized by adding Htsac (12 mg, $0.06 \mathrm{mmol}), \mathrm{AgNO}_{3}(10 \mathrm{mg}, 0.06 \mathrm{mmol})$ and tmdp $(24 \mathrm{mg}$, $0.12 \mathrm{mmol}$ ) (1:1:2 molar ratio, all solids) to dimethyl sulfoxide $(2 \mathrm{ml})$. This resulted in a clear yellow solution into which $\mathrm{CH}_{2} \mathrm{Cl}_{2}(2 \mathrm{ml})$ was diffused slowly. Crystals suitable for structural study by X-ray diffraction had appeared after $10 \mathrm{~d}$.

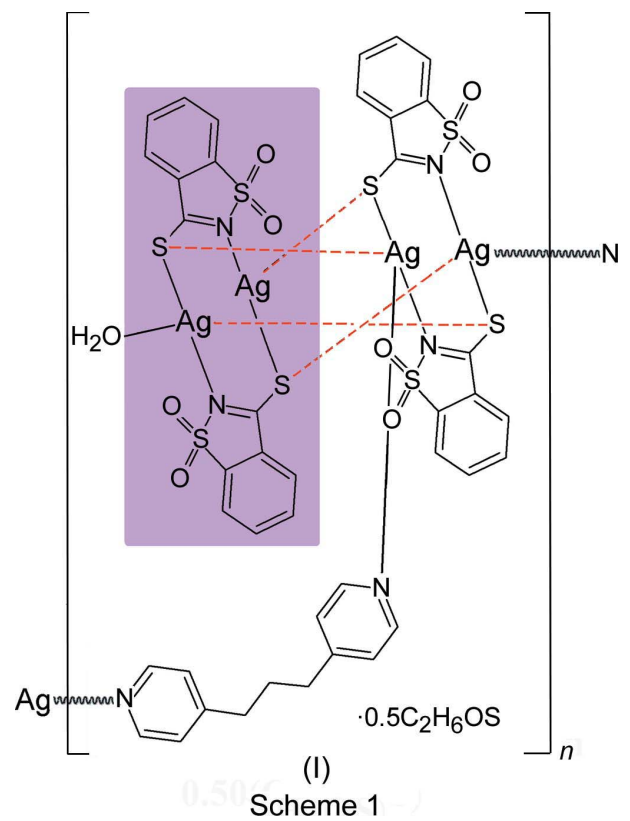

Analytical composition calculated for $\mathrm{C}_{42} \mathrm{H}_{35} \mathrm{Ag}_{4} \mathrm{~N}_{6} \mathrm{O}_{9.5} \mathrm{~S}_{8.5}$ : C 34.09, H 2.38, N 5.67\%; found: C 33.93, H 1.89, N 5.21\%. FT-IR $\left(v, \mathrm{~cm}^{-1}\right): 3444(v w), 1609(m), 1462(s), 1417(m), 1321$ $(m), 1228(m), 1168(m), 1122(w), 1001(m), 796(w), 768(w)$, $626(w), 587(m), 555(m), 534(m), 430(m)$.

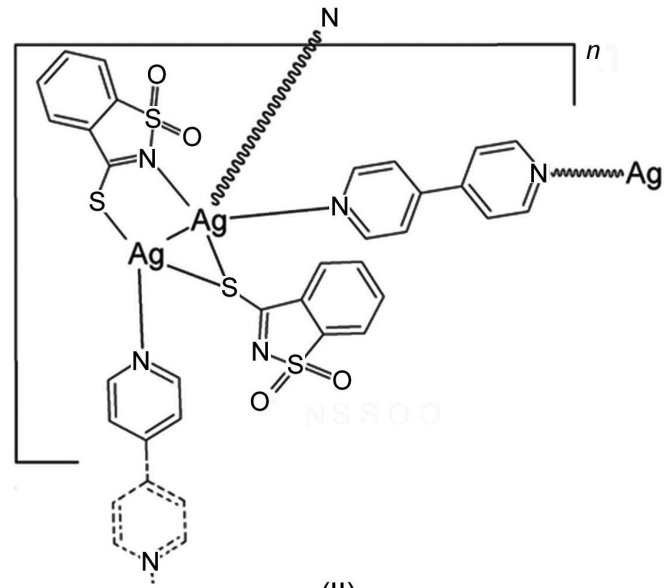

(II)

Scheme 2

\subsection{Refinement}

Crystal data, data collection and structure refinement details for (I) are summarized in Table 1. Some metric and displacement-parameter restraints were used to refine the disordered DMSO solvent, and thus facilitate convergence. The occupation factor of the two disordered moieties

Table 1

Experimental details.

Crystal data

Chemical formula

$M_{\mathrm{r}}$

Crystal system, space group

Temperature (K)

$a, b, c(\AA)$

$\alpha, \beta, \gamma\left({ }^{\circ}\right)$

$V\left(\AA^{3}\right)$

$Z$

Radiation type

$\mu\left(\mathrm{mm}^{-1}\right)$

Crystal size (mm)

Data collection

Diffractometer

Absorption correction

\section{$T_{\min }, T_{\max }$}

No. of measured, independent and observed $[I>2 \sigma(I)]$ reflections

$R_{\text {int }}$

$(\sin \theta / \lambda)_{\max }\left(\AA^{-1}\right)$

Refinement

$R\left[F^{2}>2 \sigma\left(F^{2}\right)\right], w R\left(F^{2}\right), S$

No. of reflections

No. of parameters

No. of restraints

$\mathrm{H}$-atom treatment

$\Delta \rho_{\max }, \Delta \rho_{\min }\left(\mathrm{e} \AA^{-3}\right)$

Computer programs: CrysAlis PRO (Rigaku OD, 2015), SHELXS97 (Sheldrick, 2008), $X P$ in SHELXTL (Sheldrick, 2008), SHELXL2014 (Sheldrick, 2015) and PLATON (Spek, 2009).

wouldnot behave steadily in an independent refinement, so they were forced to add up to 0.50 , roughly the oscillation mean value, after which refinement went smoothly. $\mathrm{H}$ atoms,

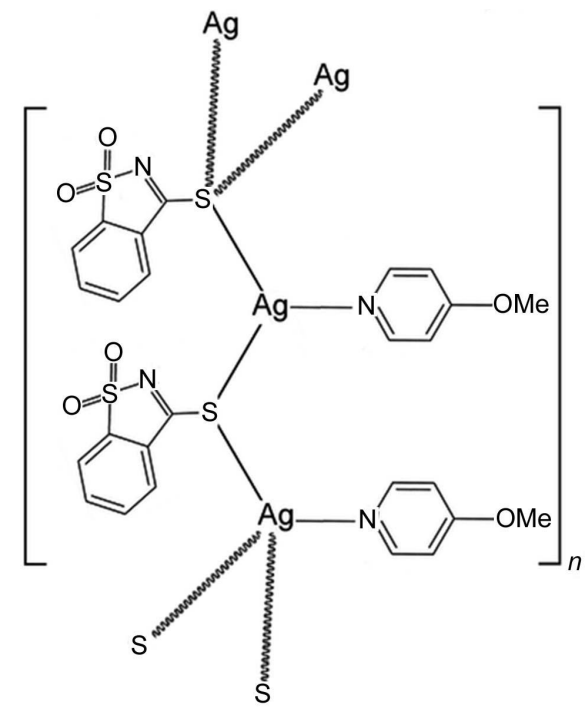

(III)

Scheme 3

except those of the water ligand and the disordered DMSO solvent molecule, were found in a difference map. Those attached to $\mathrm{C}$ atoms were finally idealized and refined as 
riding, with aromatic $\mathrm{C}-\mathrm{H}=0.93 \AA$ and $U_{\text {iso }}(\mathrm{H})=1.2 U_{\text {eq }}(\mathrm{C})$, methylene $\mathrm{C}-\mathrm{H}=0.97 \AA$ and $U_{\text {iso }}(\mathrm{H})=1.2 U_{\text {eq }}(\mathrm{C})$, and methyl $\mathrm{C}-\mathrm{H}=0.96 \AA$ and $U_{\text {iso }}(\mathrm{H})=1.5 U_{\text {eq }}(\mathrm{C})$. The $\mathrm{H}$ atoms of the water molecule were assigned where the closest potential hydrogen-bonding acceptors were located and refined with idealized geometry afterwards, with $U_{\text {iso }}(\mathrm{H})=$ $1.5 U_{\text {eq }}(\mathrm{O})$. The propylene $\mathrm{C}-\mathrm{C}$ distances were subject to a similarity restraint.

Although there are about 2500 missing reflections above $\sin (\theta) / \lambda=0.60$, we wanted to include as much high-angle data as possible. A trial refinement was made at a maximum $2 \theta$ value of $52^{\circ}$, to investigate if any introduced bias could be detected. Analysis of the results obtained in both refinements showed no perceivable differences regarding the quality of the final parameters (the maximum difference was found for a $\mathrm{C}-\mathrm{C}$ bond length, of the order of $1 / 1500$, with an s.u. value of $6 / 1500)$. But, in addition, we found that standard validation procedures (checkCIF) treated similar conflicting situations differently (in our case, a Hirshfeld difference with s.u. $\simeq$ 0.12 ), which in the refinement with the smaller data set would be ranked as a 'B alert', but as a much lighter ' $\mathrm{G}$ alert' with the whole data set. This seems to stress the benefit of using as much data as possible (irrespective of its distribution in reciprocal space), as long as uninformative noise is avoided.
Raman spectra, in turn, were gathered with a LabRAM HR Horiba Jobin Yvon Raman system equipped with two monochromator gratings and a charge-coupled device detector. A $1800 \mathrm{~g} \mathrm{~mm}^{-1}$ grating and a $50 \mu \mathrm{m}$ hole resulted in a spectral resolution of $1.5 \mathrm{~cm}^{-1}$. The spectrograph is coupled to an imaging microscope with $10 \times, 50 \times$ and $100 \times$ magnifications. The $\mathrm{He}-\mathrm{Ne}$ laser line at $632.8 \mathrm{~nm}$ is used as the excitation source. Each spectrum was averaged over eight scans with a collection time of $120 \mathrm{~s}$ for each scan. Raman spectra were acquired on powder samples at room temperature; measurements were carried out using a backscattering geometry, with $10 \times$ magnification.

Direct current (DC) electrical conductivity measurements were performed on different single crystals with carbon paint at $300 \mathrm{~K}$ and two contacts. The contacts were made with tungsten wires $(25 \mu \mathrm{m}$ diameter $)$. The samples were measured at $300 \mathrm{~K}$, applying an electrical current with voltages from +10 to $-10 \mathrm{~V}$. The electric current flowing through the sample as a consequence of the potential difference was recorded.

The samples were measured in a Quantum Design PPMS-9 connected to an external voltage source (Keithley model 2400 source-meter) and amperometer (Keithley model 6514 electrometer).

\subsection{Atoms in Molecules (AIM) analysis}

Density functional theory calculations were performed on a fragment of the polymeric complex containing the three putative Ag...Ag interactions. X-ray structures were used without geometry optimization. The Becke three-parameter exchange functional with a Lee-Yang-Parr correlation func-

IR spectra were obtained on an FT-IR-NIR Thermo Scientific Nicolet iS50 using KBr dispersions.
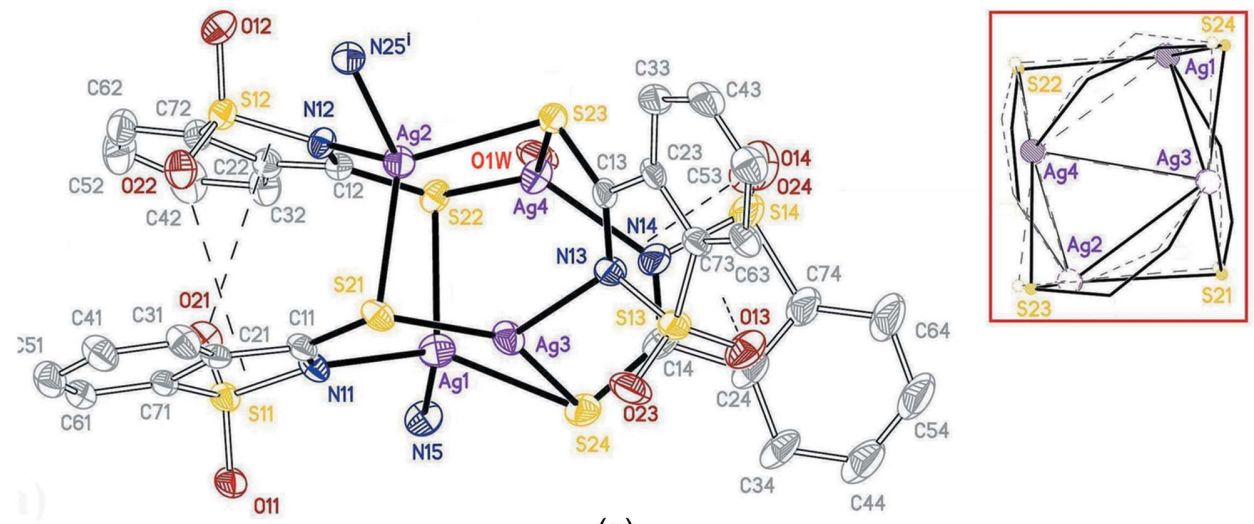

(a)

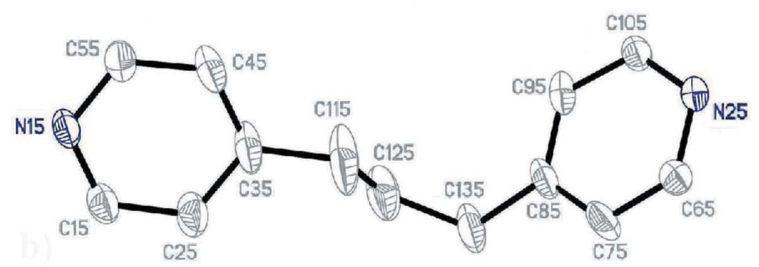

(b)

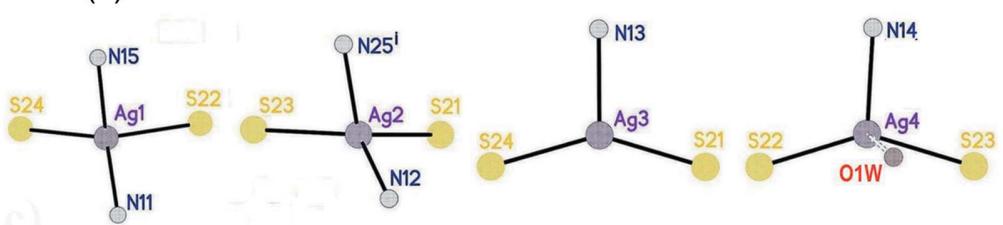

(c)

Figure 1

(a) A view of the $[\mathrm{Ag}(\mathrm{tsac})]_{4}$ conglomerate. Dashed lines denote interconglomerate $\mathrm{S}-\mathrm{O} \cdots \pi$ interactions. The inset shows a fitting of the conglomerate and its 'twofold' rotated image. (b) A view of the tmdp ligand, with displacement ellipsoids drawn at the $40 \%$ probability level. (c) The coordination polyhedra around the four independent Ag atoms. 
Table 2

Selected bond lengths in (I) $(\AA)$.

\begin{tabular}{llll}
\hline $\mathrm{Ag} 1-\mathrm{N} 15$ & $2.307(6)$ & $\mathrm{Ag} 3-\mathrm{N} 13$ & $2.317(5)$ \\
$\mathrm{Ag} 1-\mathrm{N} 11$ & $2.422(5)$ & $\mathrm{Ag} 3-\mathrm{S} 21$ & $2.416(2)$ \\
$\mathrm{Ag} 1-\mathrm{S} 22$ & $2.607(2)$ & $\mathrm{Ag} 3-\mathrm{S} 24$ & $2.472(2)$ \\
$\mathrm{Ag} 1-\mathrm{S} 24$ & $2.647(2)$ & $\mathrm{Ag} 4-\mathrm{N} 14$ & $2.354(6)$ \\
$\mathrm{Ag} 2-\mathrm{N} 12$ & $2.320(5)$ & $\mathrm{Ag} 4-\mathrm{S} 22$ & $2.461(2)$ \\
$\mathrm{Ag} 2-\mathrm{N} 25^{\mathrm{i}}$ & $2.335(6)$ & $\mathrm{Ag} 4-\mathrm{S} 23$ & $2.510(2)$ \\
$\mathrm{Ag} 2-\mathrm{S} 23$ & $2.606(2)$ & $\mathrm{Ag} 4 \cdots \mathrm{O} 1 W$ & $2.612(9)$ \\
$\mathrm{Ag} 2-\mathrm{S} 21$ & $2.615(2)$ & & \\
$\mathrm{Ag} 1 \cdots \mathrm{Ag} 3$ & $2.8307(8)$ & $\mathrm{Ag} 3 \cdots \mathrm{Ag} 4$ & $3.0692(9)$ \\
$\mathrm{Ag} 2 \cdots \mathrm{Ag} 4$ & $2.9180(8)$ & $\mathrm{Ag} 2 \cdots \mathrm{Ag} 3$ & $3.3489(8)$ \\
\hline
\end{tabular}

Symmetry code: (i) $x+1, y, z-1$.

tional (B3LYP) was used in the study (Becke, 1988, 1993; Serpe et al., 2001). The Stuttgard-Dresden effective core potential along with the SDD valence basis set was used for $\mathrm{Ag}^{\mathrm{I}}$ atoms (Fuentealba et al., 1989; Cao \& Dolg, 2002; Schwerdtfeger et al., 1989), whereas all other atoms were treated with the 6-31G basis set (Ditchfield et al., 1971; Rassolov et al., 2001). The AIM analysis of the electron density was performed using the Multiwfn program (Lu \& Chen, 2012).

\section{Results and discussion}

\subsection{Structure analysis}

The asymmetric unit of (I) consists of four $\mathrm{Ag}^{\mathrm{I}}$ cations (Ag1 to Ag4), four anionic tsac ligands (tsac1 to tsac4) and one tmdp ligand. The formula is completed by one water molecule and half of a disordered DMSO solvent molecule. The tsac ligands are unexceptional, not departing from their expected geometry, and their most relevant role is the way in which they interact with the $\mathrm{Ag}^{\mathrm{I}}$ cations, through a $\mu^{3}$ coordination involving the exocyclic $\mathrm{S}$ atoms (bridging two metal centres)

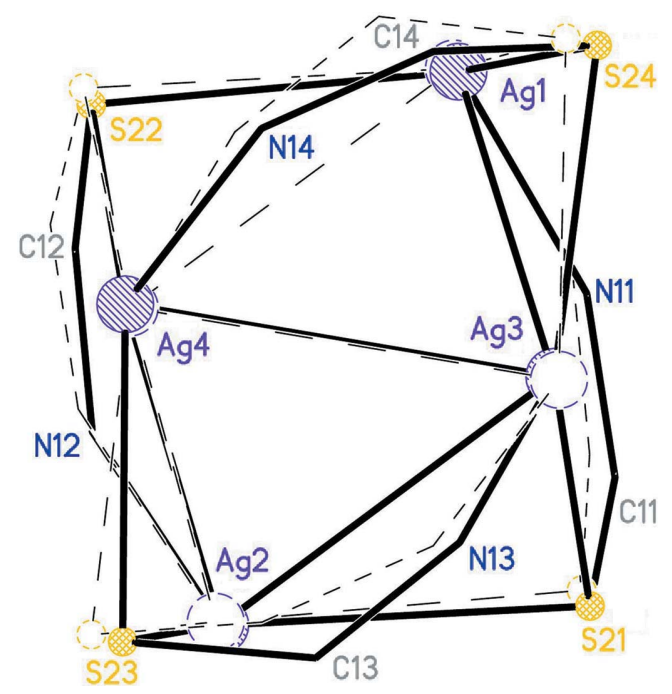

Figure 2

Least-squares fit of the $\mathrm{Ag}^{\mathrm{I}}$ cations in the $[\mathrm{AgSCN}]_{4}$ conglomerates of (I) (full lines) and XIHREM (dashed lines), disclosing the similarity in topology but differences in metrics.
Table 3

$\mathrm{S}=\mathrm{O} \cdots \pi$ bonds in (I).

$\mathrm{O} /$ perp is the perpendicular distance of the $\mathrm{O}$ atom to the plane, $\mathrm{O} \cdots \mathrm{Cg} /$ perp is the angle between the $\mathrm{O} \cdots C g$ vector and the plane normal, and $\mathrm{S}=\mathrm{C} /$ perp is the angle between the $\mathrm{S}=\mathrm{O}$ vector and the plane normal. $C g 1$ is the centroid of the S11/N11/C11/C21/C71 ring, $C g 2$ that of the S12/N12/C12/C22/ C72 ring, $C g 3$ that of the S13/N13/C13/C23/C73 and $C g 4$ that of the S14/N14/ C14/C24/C74 ring.

\begin{tabular}{lllll}
\hline $\mathrm{S}=\mathrm{O} \cdots C g$ & $\mathrm{O} \cdots C g(\AA)$ & $\mathrm{O} /$ perp $(\AA)$ & $\mathrm{O} \cdots C g /$ perp $\left(^{\circ}\right)$ & $\mathrm{S}=\mathrm{O} /$ perp $\left(^{\circ}\right)$ \\
\hline $\mathrm{S} 13=\mathrm{O} 13 \cdots C g 4$ & $3.533(8)$ & 3.428 & 30.30 & $111.5(3)$ \\
$\mathrm{S} 14=\mathrm{O} 14 \cdots C g 3$ & $3.718(9)$ & 3.440 & 13.41 & $115.5(7)$ \\
$\mathrm{S} 11=\mathrm{O} 21 \cdots C g 2$ & $3.343(6)$ & 3.124 & 46.34 & $116.9(3)$ \\
$\mathrm{S} 12=\mathrm{O} 22 \cdots C g 1$ & $3.388(6)$ & 3.244 & 41.68 & $116.6(3)$
\end{tabular}

and the endocyclic $\mathrm{N}$ atom, which define an $[\mathrm{Ag}(\mathrm{tsac})]_{4}$ conglomerate (Fig. 1a). Table 2 presents selected coordination distances.

The fact that the four anions coordinate in a similar way is reflected in the IR spectrum, which shows only one absorption band for the anion. In the same spectrum (see Fig. S1 in the supporting information), the bands corresponding to the nitrogenated colligate can also be observed.

The resulting globular clusters are made up of two extremely similar $[\mathrm{Ag}(\mathrm{tsac})]_{2}$ rings (highlighted in Scheme 1), further connected through four $\mathrm{S}-\mathrm{Ag}$ bonds. In this sense, the cluster can be considered as a dimer of dimers. Even if this particular choice of rings is rather arbitrary, due to the two possible $\mathrm{S}-\mathrm{Ag}$ bonds for each $\mathrm{S}$ atom, the one we appoint is sustained by a plausibility argument based on symmetry reasons, viz. the whole $[\mathrm{Ag}(\mathrm{tsac})]_{4}$ group, as described herein, presents a kind of twofold pseudosymmetry, relating Ag1 with Ag2, and Ag3 with Ag4, as shown in the inset in Fig. 1. A search in the Cambridge Structural Database (CSD, Version 5.38 and updates; Groom et al., 2016) disclosed that a very similar arrangement has been reported in Dennehy et al. (2007) (CSD refcode XIHREM), whose nucleus is also made up of two dimers linked by four $\mathrm{S}-\mathrm{Ag}$ bonds, in a disposition analogous to that in (I). This similarity is confirmed in Fig. 2, which shows a least-squares fit of the $\mathrm{Ag}^{\mathrm{I}}$ cations in both nuclei, making the identical topologies of both clusters apparent, while disclosing some significant metric differences, as discussed below.

The cohesion of the $[\mathrm{Ag}(\mathrm{tsac})]_{4}$ group in (I) is further enhanced by four intramolecular $\mathrm{S}=\mathrm{O} \cdots \pi$ bonds, presented in Table 3 and shown in Fig. 1(a) as dashed lines. It is to be noted that all the exocyclic $\mathrm{SO}_{2}$ groups, as well as all the fivemembered rings are involved in these interactions.

The 4,4'-(propane-1,3-diyl)dipyridine (tmdp) molecule departs severely from coplanarity (Fig. 1b), with the planes of the terminal pyridine groups, denoted Py(N15) and Py(N25), defining dihedral angles with the $\mathrm{C} 115-\mathrm{C} 135$ central group of $113.2(2)$ and $80.7(2)^{\circ}$, respectively, and $34.5(2)^{\circ}$ with each other. The elongated ligand acts as a spacer between neighbouring $[\mathrm{Ag}(\mathrm{tsac})]_{4}$ clusters, linking them (through atoms N15 and N25) to define chains parallel to [101] (Fig. 3). With the inclusion of these lateral tmdp ligands, Ag1 and Ag2 end up being four-coordinated in an $\mathrm{AgN}_{2} \mathrm{~S}_{2}$ distorted tetrahedral 


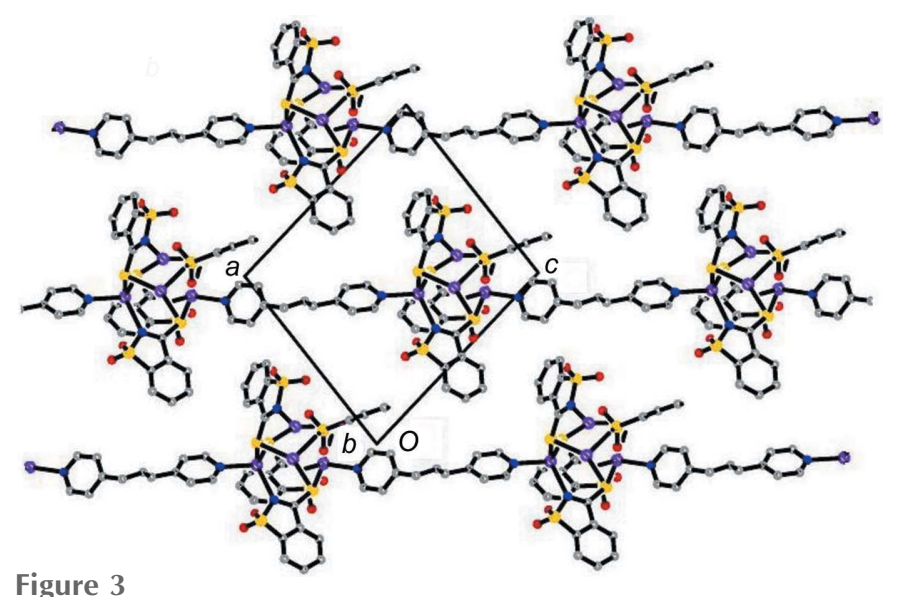

The parallel [101] chains, showing the 'knot' versus 'thread' disposition optimizing compactness.

environment, while $\mathrm{Ag} 3$ and $\mathrm{Ag} 4$ are three-coordinated in a quasi-planar $\mathrm{AgNS}_{2}$ environment, with the cations lying 0.06 (2) and 0.14 (2) $\AA$ from the least-squares plane defined by the ligands. In this sense, it is worth mentioning that water molecule $\mathrm{O} 1 \mathrm{~W}$ occupies a pseudo-apical site in the $\mathrm{Ag} 4$ polyhedron, at a quasi-coordination $\mathrm{Ag}$...O distance of 2.612 (9) $\AA$. Even if rather weak (AIM calculations suggest it to be comparable to a medium-strength $\mathrm{O} \cdots \mathrm{H}$ hydrogen bond), this type of $\mathrm{Ag}^{\mathrm{I}} \cdots \mathrm{OW}$ interaction is not unusual; a search in the CSD found 130 cases of a comparable $\mathrm{Ag}^{\mathrm{I}} X_{3-} \mathrm{OW}(X=\mathrm{S}, \mathrm{N}$ or $\mathrm{O})$ polyhedra, with a mean $\mathrm{Ag}-\mathrm{O} W$ coordination distance of 2.50 (15) $\AA$ and a 2.135-2.855 $\AA$ span, with the present case lying in the longest quartile.

The resulting coordination of each $\mathrm{Ag}^{\mathrm{I}}$ cation can be seen qualitatively in Figs. 1(a) and 1(c), and quantitative details can be found in Table 2 . The difference in coordination numbers is reflected in the $\mathrm{Ag}-\mathrm{S}$ and $\mathrm{Ag}-\mathrm{N}$ coordination distances, distinctly shorter in Ag3 and Ag4. The corresponding bond valence, as calculated by the program Valence (Brown, 2002), remains fairly constant, around the expected $1+$ charge of the cation, viz. $\mathrm{Ag} 1=0.943, \mathrm{Ag} 2=1.003, \mathrm{Ag} 3=1.075$ and $\mathrm{Ag} 4=$ 1.036, with a total for all four cations of 4.057 .

The one-dimensional substructure (the elemental unit building up the crystal structure) resembles a thin wire with evenly spaced bulky protuberances on it. In the packing process, the chains align parallel to each other but shift along the chain direction so as to have the protuberances facing the thin section in neighbouring chains (Fig. 3), and thus optimizing compactness. They are interconnected by weaker (interchain) noncovalent bonds, as well as a few more, mediated by the water ligands and DMSO solvent molecules (Table 4) interspersed between the chains. Regarding the latter DMSO molecule, it makes an $\mathrm{S}=\mathrm{O} \cdots \mathrm{O}=\mathrm{S}$ short contact to the $\mathrm{S} 4-\mathrm{O} 24$ group $[\mathrm{O} \cdots \mathrm{O}=2.871$ (2) $\AA$ ].

\subsection{Argentophilic interactions}

A distinctive characteristic of silver thiosaccharinates is the fact that the different bridging modes displayed by the anion can lead to intricate crystal structures with short Ag...Ag
Table 4

Hydrogen-bond geometry $\left(\AA,^{\circ}\right)$.

\begin{tabular}{|c|c|c|c|c|}
\hline$D-\mathrm{H} \cdots A$ & $D-\mathrm{H}$ & $\mathrm{H} \cdots A$ & $D \cdots A$ & $D-\mathrm{H} \cdots A$ \\
\hline $\mathrm{O} 1 W-\mathrm{H} 1 W B \cdots \mathrm{O} 14$ & $0.95(10)$ & $2.59(11)$ & $3.425(18)$ & $147(9)$ \\
\hline $\mathrm{O} 1 W-\mathrm{H} 1 W B \cdots \mathrm{O} 24$ & $0.95(10)$ & $2.59(8)$ & $3.072(18)$ & $112(8)$ \\
\hline $\mathrm{O} 1 W-\mathrm{H} 1 W A \cdots \mathrm{O} 1 A^{\mathrm{i}}$ & $0.96(9)$ & $2.05(18)$ & $2.65(2)$ & $119(12)$ \\
\hline $\mathrm{C} 125-\mathrm{H} 12 B \cdots \mathrm{O} 1 W^{\mathrm{i}}$ & 0.97 & 2.53 & $3.369(17)$ & 144 \\
\hline $\mathrm{C} 44-\mathrm{H} 44 \cdots \mathrm{O} 11^{\mathrm{ii}}$ & 0.93 & 2.52 & $3.260(13)$ & 137 \\
\hline $\mathrm{C} 53-\mathrm{H} 53 \cdots \mathrm{S} 21^{\mathrm{iii}}$ & 0.93 & 2.86 & $3.572(9)$ & 134 \\
\hline $\mathrm{C} 75-\mathrm{H} 75 \cdots \mathrm{O} 24^{\mathrm{iv}}$ & 0.93 & 2.41 & $3.284(16)$ & 158 \\
\hline $\mathrm{C} 105-\mathrm{H} 105 \cdots \mathrm{S} 23^{\mathrm{v}}$ & 0.93 & 2.82 & $3.508(9)$ & 132 \\
\hline
\end{tabular}

Symmetry codes: (i) $-x+1,-y+1,-z+1$; (ii) $-x+1,-y,-z+1$; (iii) $-x+2$, $-y,-z ;$ (iv) $x, y, z+1 ;$ (v) $x-1, y, z+1$.

distances. When these short contacts are interactive (and not the mere result of packing constraints), they are called argentophilic interactions (Kristiansson, 2001; Castiñeiras et al., 2006; Schmidbaur \& Schier, 2015).

These metallophilic contacts can be formed with or without the assistance of an anion or any other ligand bridging the metal cations. The proximity of the two $\mathrm{Ag}^{\mathrm{I}}$ atoms may lead to strong $d^{10}-d^{10}$ interactions and, as a rule of thumb, they are usually considered to be present for $\mathrm{Ag} \cdot \cdots \mathrm{Ag}$ distances shorter than $3.44 \AA$ (twice the $\mathrm{Ag}^{\mathrm{I}}$ van der Waals radius; Bondi, 1964). In the present structure of (I), there are four of these short Ag...Ag distances (Table 2).

A CSD survey of reported Ag...Ag distances in similar complexes disclosed that the 2.8307 (8) $\AA$ value in (I) is the second shortest found in silver thiosaccharinates, second only to the extremely effective centrosymmetric double bridge $\left[\mu_{2^{-}}\right.$ $\left.\kappa^{2} S: S\right]_{2}=\left(\mathrm{SAg}_{2} \mathrm{~S}\right)$ present in XIHQUB (Dennehy et al., 2008) and leading to a value of $2.789 \AA$. The remaining short distances found involve either (i) a combination of the $\mu_{2}$ $\kappa^{2} N: S$ bite on one side plus a $\mu_{2}-\kappa^{2} S: S$ bridge on the other, as in EPUMUZ (Dennehy et al., 2016; $d=2.886 \AA$ ), or (ii) plainly the same head-to-tail $[\mathrm{Ag}(\mathrm{tsac})]_{2}$ dimers found in (I). As a comparison, the values in the already discussed topologically similar XIHREM (2.952 and $3.000 \AA)$, in spite of being within what is usually considered 'ligand-assisted' argentophilic interaction distances, are nonetheless significantly longer than the shortest distances found in (I), viz. 2.830 and $2.918 \AA$.

Argentophilic interactions are currently being studied both from experimental and theoretical points of view (e.g. Lamming et al., 2017). Among the former studies, some reports in the literature show that the $\mathrm{Ag} \cdot \mathrm{Ag}$ stretching vibration may reveal the eventual presence (and strength) of a silver-silver interaction (Morishima et al., 2014; Harvey, 1996). We have evaluated argentophilic interactions by means of Raman spectroscopy in a previous work (Dennehy et al., 2016). The Raman spectrum of (I) (see Fig. S2 in the supporting information) also shows a weak stretching band at $78 \mathrm{~cm}^{-1}$ that could be assigned to the $\mathrm{Ag} \cdots \mathrm{Ag}$ vibrational mode and is consistent with the presence of an $\mathrm{Ag} \cdots \mathrm{Ag}$ metallophilic interaction in this complex. The $\mathrm{Ag}-\mathrm{S}$ stretching modes are reflected in a band appearing at $249 \mathrm{~cm}^{-1}$ (Martina et al., 2012). The bands at $366 \mathrm{~cm}^{-1}$ could be attributed to $\mathrm{Ag}-\mathrm{N}$ stretching vibrations, while the bands at 116 and $153 \mathrm{~cm}^{-1}$ could be related to other $\mathrm{Ag}-\mathrm{N}$ modes. 
To complement those experimental studies, we have also approached the problem from a theoretical point of view, by way of an Atoms in Molecules (AIM) analysis (Bader, 1990), which for the detection of interatomic interactions analyses the values and shape of the calculated electron-density curve $[\rho(r)]$, its gradient $[\nabla(r)]$ and its Laplacian $\left[\nabla^{2} \rho(r)\right]$. (Further

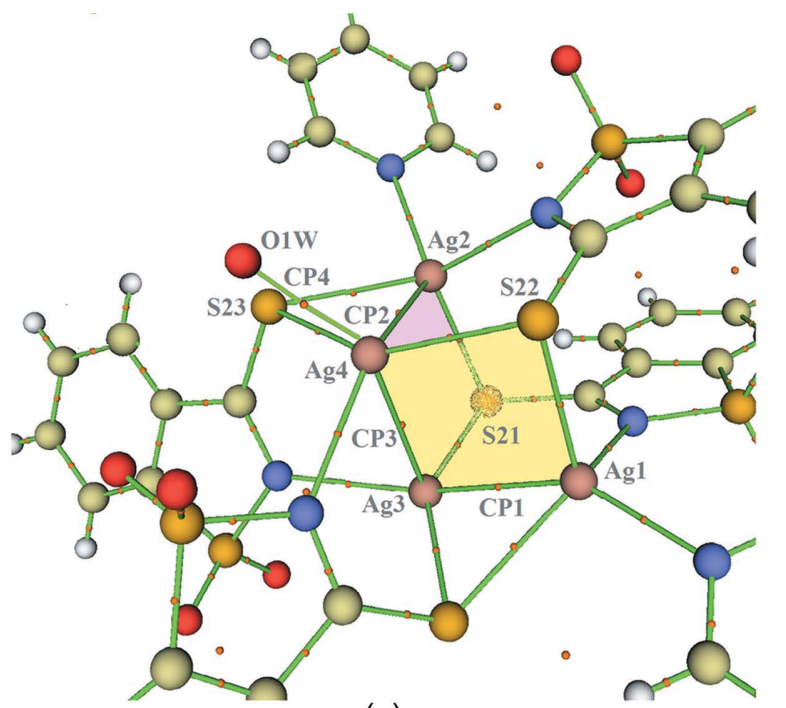

(a)

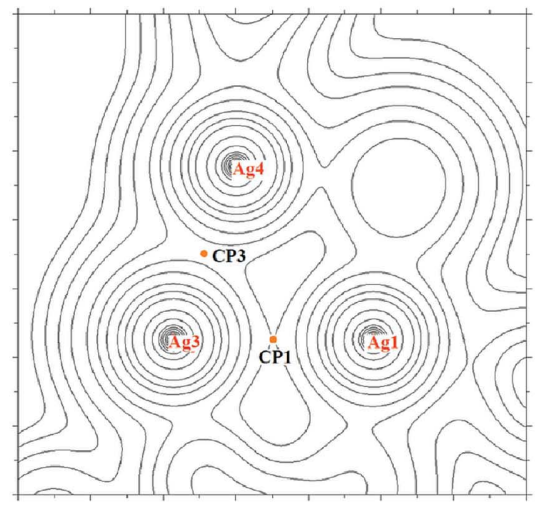

(b)

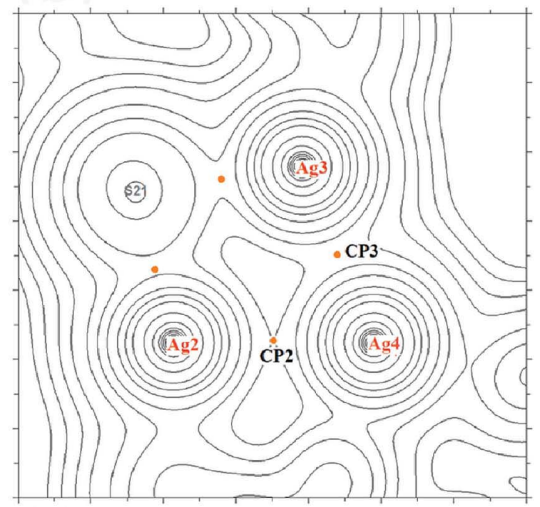

(c)

Figure 4

(a) Selected BCPs (orange balls) in (I). (b) Contour lines of the charge density in the $\mathrm{Ag} 1-\mathrm{Ag} 3-\mathrm{Ag} 4$ plane [highlighted in yellow in part $(a)$ ]. (c) Contour lines of the charge density in the Ag2-Ag3-Ag4 plane [highlighted in pink in part (a)]. Note the lack of BCPs in the Ag2$\mathrm{Ag} 3$ and $\mathrm{Ag} 1-\mathrm{Ag} 4$ intermetallic zones.
Table 5

Comparison of the relative strengths of argentophilic interactions in (I) with those of selected covalent and noncovalent interactions.

$C g 1$ is the centroid of the S11/N11/C11/C21/C71 ring, $C g 2$ that of the S12/N12/ C12/C22/C72 ring, $C g 3$ that of the S13/N13/C13/C23/C73 and $C g 4$ that of the S14/N14/C14/C24/C74 ring.

\begin{tabular}{|c|c|c|c|c|c|}
\hline Interaction & \#CP & Contact & Distance & $\rho(r)(\times 100)$ & $\nabla^{2} \rho(r)(\times 10)$ \\
\hline \multirow[t]{4}{*}{$\mathrm{Ag} \cdots \mathrm{Ag}$} & CP1 & $\mathrm{Ag} 1 \cdots \mathrm{Ag} 3$ & $2.8307(8)$ & 3.23 & 0.80 \\
\hline & $\mathrm{CP} 3$ & $\mathrm{Ag} 3 \cdots \mathrm{Ag} 4$ & $3.0692(9)$ & 1.99 & 0.51 \\
\hline & $\mathrm{CP} 2$ & $\mathrm{Ag} 4 \cdots \mathrm{Ag} 2$ & $2.9180(8)$ & 2.75 & 0.69 \\
\hline & $\mathrm{CP} 4$ & $\mathrm{Ag} 4 \cdots \mathrm{O} 1 \mathrm{~W}$ & $2.612(9)$ & 2.66 & 0.85 \\
\hline \multirow{4}{*}{$\mathrm{O} \cdots \pi$} & & $\mathrm{O} 13 \cdots \mathrm{Cg} 4$ & $3.533(8)$ & 0.37 & 0.14 \\
\hline & & $\mathrm{O} 14 \cdots \mathrm{Cg} 3$ & $3.718(9)$ & 0.36 & 0.15 \\
\hline & & $\mathrm{O} 21 \cdots \mathrm{Cg} 2$ & $3.343(6)$ & 0.68 & 0.25 \\
\hline & & $\mathrm{O} 22 \cdots \mathrm{Cg} 1$ & $3.388(6)$ & 0.53 & 0.19 \\
\hline \multirow[t]{8}{*}{$\mathrm{S}-\mathrm{Ag}$} & & $\mathrm{S} 21-\mathrm{Ag} 3$ & $2.416(2)$ & 7.21 & 1.90 \\
\hline & & $\mathrm{S} 21-\mathrm{Ag} 2$ & $2.615(2)$ & 4.77 & 1.23 \\
\hline & & S22-Ag1 & $2.607(2)$ & 4.85 & 1.25 \\
\hline & & $\mathrm{S} 22-\mathrm{Ag} 4$ & $2.461(2)$ & 6.59 & 1.74 \\
\hline & & $\mathrm{S} 23-\mathrm{Ag} 2$ & $2.606(2)$ & 4.90 & 1.25 \\
\hline & & $\mathrm{S} 23-\mathrm{Ag} 4$ & $2.510(2)$ & 6.03 & 1.50 \\
\hline & & S24-Ag1 & $2.647(2)$ & 4.63 & 1.17 \\
\hline & & S24-Ag3 & $2.472(2)$ & 6.43 & 1.59 \\
\hline
\end{tabular}

information on the method is given in the supporting information.)

The calculations made showed that there was a significant accumulation of electron density between $\mathrm{Ag} 1 \cdots \mathrm{Ag} 3$, Ag2 $\cdots$ Ag4 and Ag3 $\cdots$ Ag4, confirmed by the presence of bond critical points (BCPs). In contrast, there was no BCP in the intermetallic region between $\mathrm{Ag} 2 \cdots \mathrm{Ag} 3$, in accordance with the longer intermetallic distance (Fig. 4).

This kind of analysis has the advantage of allowing quantitative estimations of the interaction strengths, at least in relative terms, by comparison with other more familiar interactions in the structure.

This information is presented in Table 5, where in the two rightmost columns, the electron density and its Laplacian at the CP are shown.

From the values therein, it is clear that the strengths of the argentophilic interactions lie midway between those of coordination bonds and the weaker noncovalent interactions. However, the $\mathrm{Ag} 1 \cdots \mathrm{Ag} 3$ contact is almost twice as strong as the remaining ones in Table 5, and comparable to the long Ag4-O $1 W$ coordination bond, thus highlighting its relevance.

\subsection{Electrical conductivity}

It has been stated that, in addition to the techniques mentioned above, as well as the short intermetallic distances, argentophilic interactions could be evidenced via some further physical properties of the complexes, such as electrical conductivity (EC) (Jansen, 1987; Su et al., 2000). In order to obtain clues about this eventual EC-argentophilicity relationship (the latter as qualitatively evaluated by the shortest $\mathrm{Ag} \cdot . \mathrm{Ag}$ distance in the structure) or on the way in which the crystal structure might influence this behaviour, we thought of comparing the EC values in (I) with those of related polymeric complexes presenting argentophilic contacts of varied strength 
Table 6

Electric conductivity and argentophilic interactions in (I), (II) and (III).

\begin{tabular}{llll}
\hline Compound & $\mathrm{EC}\left(\mathrm{S} \mathrm{cm}^{-1}\right)$ & $\mathrm{Ag} \cdots \mathrm{Ag}(\AA)$ & Bridging mode \\
\hline (I) & $2.5 \times 10^{-8}$ & 2.830 & $\mathrm{~N}-\mathrm{Ag}$ \\
(II) & $2.9 \times 10^{-7}$ & 2.886 & $\mathrm{~N}-\mathrm{Ag}$ \\
(III) & $9.5 \times 10^{-3}$ & 3.024 & $\mathrm{~S}-\mathrm{Ag}$ \\
\hline
\end{tabular}

(= intermetallic distance), but with a rather similar [as in structure (II)] or a totally different [as in structure (III)] bridging connectivity (Scheme 2). With this idea in mind, we measured the corresponding ECs at $T=300 \mathrm{~K}$ in single crystals of all three compounds, wired with tungsten tips connected through a graphite tincture (details of the set-up can be seen in Fig. $5 a$ ) to end up with the curves shown in Fig. 5(b) and the values reported in Table 6. The ECs obtained indicate that all three polymers could be semiconductors with moderate conductivity. A comparative inspection suggests an extremely feeble (if any) correlation between the EC and the argentophilic interaction, but at the same time suggest a strong link of the EC with the way in which connectivity is achieved (Scheme 2). Thus, compound (III), which bridges metal centres through $\mathrm{S}-\mathrm{Ag}$ junctions, presents the largest $\mathrm{EC}$, surpassing the remaining two by four orders of magnitude. On
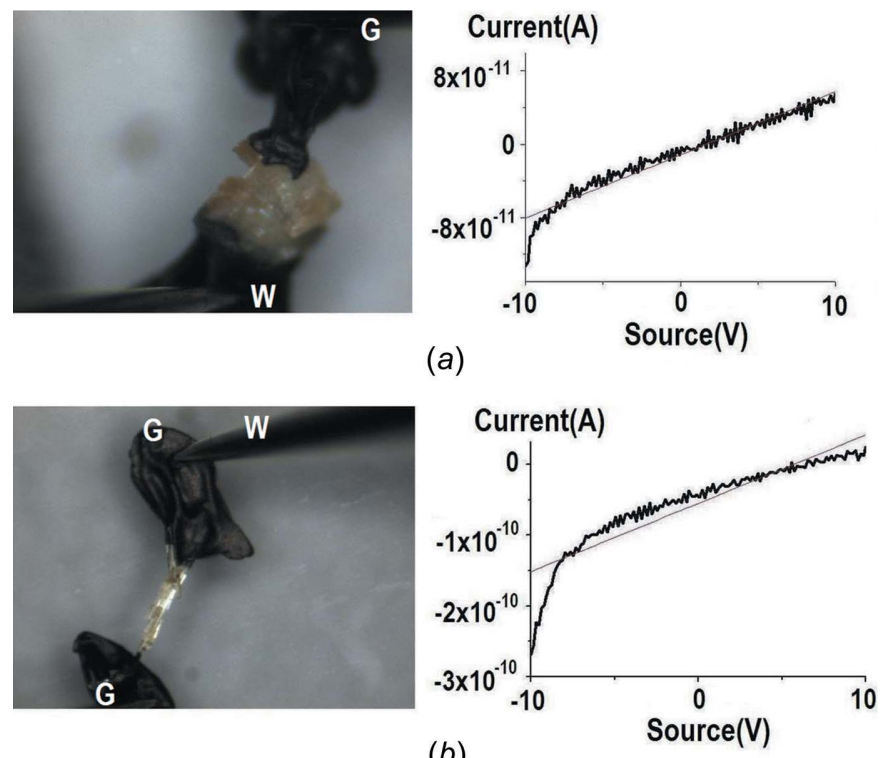

(b)
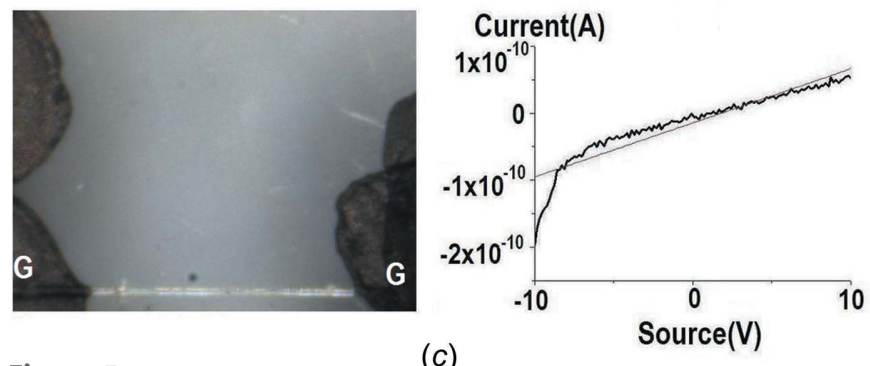

Figure 5

(c)

(a) Left column: the set-up used for the measurement of electrical conductivity in monocrystals of $(a)$ (I), (b) (II) and (c) (III). Right column: the corresponding EC curves. Lettering code: $\mathrm{G}$ is graphite paste and $\mathrm{W}$ is tungsten wires. the other hand, in structures (I) and (II), where the bridges are formed via the $\mathrm{N}-\mathrm{Ag}$ bonds of nitrogenated bases, the conductivity decreases dramatically. Analysis of these results seems to point to the $\mathrm{Ag}-\mathrm{S}$ versus $\mathrm{S}-\mathrm{N}$ connection mode of the bridging anion as a decisive factor, much more relevant than intermetallic interaction, and correlates with previously published data where the metal-sulfur connectivity seems to be the key in the electrical conductivity values versus metalmetal distances (Givaja et al., 2012). It is clear that with such a poor casuistry, no conclusive assertion can be made on the subject and many more cases ought to be analyzed, but it certainly seems to be a topic worth considering in any further structural work on polymeric silver complexes.

\section{Funding information}

Funding for this research was provided by: NPCyT (project No. PME 2006-01113, for the purchase of the Oxford Gemini CCD diffractometer); SGCyT-UNS (project No. 24/Q075).

\section{References}

Bader, R. F. W. (1990). In Atoms in Molecules - a Quantum Theory. Oxford University Press.

Becke, A. D. (1988). Phys. Rev. A, 38, 3098-3100.

Becke, A. D. (1993). J. Chem. Phys. 98, 5648-5652.

Bondi, A. (1964). J. Phys. Chem. 68, 441-451.

Brown, I. D. (2002). In The Chemical Bond in Inorganic Chemistry: The Bond Valence Model. Oxford University Press.

Burrow, R. A., Belmonte, G. Z., Dorn, V. \& Dennehy, M. (2016). Inorg. Chim. Acta, 450, 39-49.

Cao, X. Y. \& Dolg, M. (2002). J. Mol. Struct. Theochem, 581, 139-147.

Castiñeiras, A., García-Santos, I., Dehnen, S. \& Sevillano, P. (2006). Polyhedron, 25, 3653-3660.

Dennehy, M., Delgado, F., Freire, E., Halac, E. \& Baggio, R. (2016). Acta Cryst. C72, 572-577.

Dennehy, M., Ferullo, R. M., Quinzani, O. V., Mandolesi, S. D., Castellani, N. \& Jennings, M. (2008). Polyhedron, 27, 2243-2250.

Dennehy, M., Quinzani, O. V., Granados, A. \& Burrow, R. A. (2010). Polyhedron, 29, 1344-1352.

Dennehy, M., Quinzani, O. V. \& Jennings, M. (2007). J. Mol. Struct. 841, 110-117.

Ditchfield, R., Hehre, W. J. \& Pople, J. A. (1971). J. Chem. Phys. 54, 724-728.

Fuentealba, P., Preuss, H., Stoll, H. \& Szentpaly, L. (1989). Chem. Phys. Lett. 89, 418-422.

Givaja, G., Amo-Ochoa, P., Gómez-García, C. J. \& Zamora, F. (2012). Chem. Soc. Rev. 41, 115-147.

Groom, C. R., Bruno, I. J., Lightfoot, M. P. \& Ward, S. C. (2016). Acta Cryst. B72, 171-179.

Harvey, P. D. (1996). Coord. Chem. Rev. 153, 175-198.

Jansen, M. (1987). Angew. Chem. 99, 1136-1149.

Kristiansson, O. (2001). Inorg. Chem. 40, 5058-5059.

Lamming, G., Kolokotroni, J., Harrison, T., Penfold, T. J., Clegg, W., Waddell, P. G., Probert, M. R. \& Houlton, A. (2017). Cryst. Growth Des. 17, 5935-5944.

Lu, T. \& Chen, F. (2012). J. Comput. Chem. 33, 580-592.

Martina, I., Wiesinger, R., Jembrih-Simbürger, D. \& Schreiner, M. (2012). e-Preserv. Sci. 9, 1-8.

Morishima, Y., Young, D. J. \& Fujisawa, K. (2014). Dalton Trans. 43, 15915-15928.

Rassolov, V. A., Ratner, M. A., Pople, J. A., Redfern, P. C. \& Curtiss, L. A. (2001). J. Comput. Chem. 22, 976-984.

Rigaku OD (2015). CrysAlis PRO. Rigaku Oxford Diffraction, Yarnton, Oxfordshire, England. 
Schmidbaur, H. \& Schier, A. (2015). Angew. Chem. Int. Ed. 54, 746-784. Schwerdtfeger, P., Dolg, M., Schwarz, W. H. E., Bowmaker, G. A. \& Boyd, P. D. W. J. (1989). Chem. Phys. 91, 1762-1774.

Serpe, A., Artizzu, F., Marchio, L., Mercuri, M. L., Pilia, L. \& Deplano, P. (2001). Cryst. Growth Des. 2011, 1278-1286.
Sheldrick, G. M. (2008). Acta Cryst. A64, 112-122.

Sheldrick, G. M. (2015). Acta Cryst. C71, 3-8.

Spek, A. L. (2009). Acta Cryst. D65, 148-155.

Su, W. P., Hong, M. C., Weng, J. B., Cao, R. \& Lu, S. (2000). Angew. Chem. Int. Ed. 39, 2911-2914. 


\section{supporting information}

Acta Cryst. (2018). C74, 186-193 [https://doi.org/10.1107/S2053229618000128]

\section{Structure and electrical properties of a one-dimensional polymeric silver thio- saccharinate complex with argentophilic interactions}

\section{Mariana Dennehy, Pilar Amo-Ochoa, Eleonora Freire, Sebastián Suárez, Emilia Halac and Ricardo Baggio}

Computing details

Data collection: CrysAlis PRO (Rigaku OD, 2015); cell refinement: CrysAlis PRO (Rigaku OD, 2015); data reduction: CrysAlis PRO (Rigaku OD, 2015); program(s) used to solve structure: SHELXS97 (Sheldrick, 2008); program(s) used to refine structure: SHELXL2014 (Sheldrick, 2015); molecular graphics: XP in SHELXTL (Sheldrick, 2008); software used to prepare material for publication: SHELXL2014 (Sheldrick, 2015) and PLATON (Spek, 2009).

catena-Poly [[[aquatetrakis $\left(\mu_{3}-1,1-\right.$ dioxo-1,2-benzisothiazole-3-thiolato- $\left.\kappa^{3} \mathrm{~N}: S^{3}: S^{3}\right)$ tetrasilver $\left.(\mathrm{I})\right]$ $\mu_{2}-4,4$ '-(propane-1,3-dyl)dipyridine- $\left.\kappa^{2} N: N^{\prime}\right]$ dimethyl sulfoxide hemisolvate]

Crystal data

$\left[\mathrm{Ag}_{4}\left(\mathrm{C}_{7} \mathrm{H}_{4} \mathrm{NO}_{2} \mathrm{~S}_{2}\right)_{4}\left(\mathrm{C}_{13} \mathrm{H}_{14} \mathrm{~N}_{2}\right)\left(\mathrm{H}_{2} \mathrm{O}\right)\right] \cdot 0.5 \mathrm{C}_{2} \mathrm{H}_{6} \mathrm{OS}$

$M_{r}=1479.75$

Triclinic, $P \overline{1}$

$a=13.7710(4) \AA$

$b=13.9822(4) \AA$

$c=14.7181(5) \AA$

$\alpha=81.074(3)^{\circ}$

$\beta=79.523(3)^{\circ}$

$\gamma=73.152(3)^{\circ}$

$V=2651.23(15) \AA^{3}$

\section{Data collection}

Rigaku OD Xcalibur Eos Gemini diffractometer

Radiation source: fine-focus sealed X-ray tube, Enhance (Mo) X-ray Source

Graphite monochromator

Detector resolution: 16.0604 pixels $\mathrm{mm}^{-1}$

$\omega$ scans

Absorption correction: multi-scan (CrysAlis PRO; Rigaku OD, 2015)

Refinement

Refinement on $F^{2}$

Least-squares matrix: full

$R\left[F^{2}>2 \sigma\left(F^{2}\right)\right]=0.056$

$w R\left(F^{2}\right)=0.158$

$S=1.03$
$Z=2$

$F(000)=1458$

$D_{\mathrm{x}}=1.854 \mathrm{Mg} \mathrm{m}^{-3}$

Mo $K \alpha$ radiation, $\lambda=0.71073 \AA$

Cell parameters from 6300 reflections

$\theta=3.6-26.1^{\circ}$

$\mu=1.85 \mathrm{~mm}^{-1}$

$T=290 \mathrm{~K}$

Fragment, yellow

$0.42 \times 0.30 \times 0.10 \mathrm{~mm}$

$T_{\min }=0.50, T_{\max }=0.85$

26030 measured reflections

11551 independent reflections

7060 reflections with $I>2 \sigma(I)$

$R_{\text {int }}=0.032$

$\theta_{\max }=29.0^{\circ}, \theta_{\min }=3.0^{\circ}$

$h=-17 \rightarrow 14$

$k=-19 \rightarrow 18$

$l=-19 \rightarrow 19$

11551 reflections

659 parameters

62 restraints

Hydrogen site location: mixed 
$\mathrm{H}$ atoms treated by a mixture of independent and constrained refinement

$w=1 /\left[\sigma^{2}\left(F_{\mathrm{o}}^{2}\right)+(0.0606 P)^{2}+6.6052 P\right]$

where $P=\left(F_{\mathrm{o}}^{2}+2 F_{\mathrm{c}}^{2}\right) / 3$

$$
\begin{aligned}
& (\Delta / \sigma)_{\max }=0.001 \\
& \Delta \rho_{\max }=1.17 \text { e } \AA^{-3} \\
& \Delta \rho_{\min }=-0.85 \text { e } \AA^{-3}
\end{aligned}
$$

Special details

Geometry. All esds (except the esd in the dihedral angle between two 1.s. planes) are estimated using the full covariance matrix. The cell esds are taken into account individually in the estimation of esds in distances, angles and torsion angles; correlations between esds in cell parameters are only used when they are defined by crystal symmetry. An approximate

\begin{tabular}{|c|c|c|c|c|c|}
\hline & $x$ & $y$ & $z$ & $U_{\text {iso }} * / U_{\text {eq }}$ & Occ. $(<1)$ \\
\hline Ag1 & $0.65543(5)$ & $0.22505(5)$ & $0.46035(4)$ & 0.07203 (19) & \\
\hline Ag2 & $0.88094(4)$ & 0.27268 & $0.23224(4)$ & $0.06322(17)$ & \\
\hline Ag3 & $0.76014(5)$ & $0.09579(5)$ & 0.32270 & $0.06839(18)$ & \\
\hline Ag4 & $0.66209(5)$ & 0.30577 & $0.23040(5)$ & $0.07152(19)$ & \\
\hline $\mathrm{S} 11$ & $0.84966(13)$ & $0.21588(13)$ & $0.59344(11)$ & $0.0551(4)$ & \\
\hline $\mathrm{S} 21$ & $0.92920(14)$ & $0.10318(14)$ & $0.33902(11)$ & $0.0610(5)$ & \\
\hline O11 & $0.8151(4)$ & 0.1529 & $0.6700(3)$ & 0.0688 (13) & \\
\hline $\mathrm{O} 21$ & $0.8090(4)$ & $0.3215(4)$ & $0.5947(4)$ & $0.0749(14)$ & \\
\hline N11 & $0.8288(4)$ & 0.1844 & 0.4955 & $0.0562(14)$ & \\
\hline C11 & $0.9170(5)$ & $0.1469(5)$ & $0.4442(4)$ & $0.0538(16)$ & \\
\hline $\mathrm{C} 21$ & $1.0095(5)$ & $0.1425(5)$ & $0.4830(4)$ & $0.0512(15)$ & \\
\hline C31 & $1.1124(6)$ & $0.1069(6)$ & $0.4467(5)$ & $0.069(2)$ & \\
\hline H31 & 1.131614 & 0.079417 & 0.390412 & $0.083^{*}$ & \\
\hline $\mathrm{C} 41$ & $1.1838(6)$ & $0.1136(7)$ & $0.4961(6)$ & $0.084(3)$ & \\
\hline H41 & 1.252856 & 0.091592 & 0.472183 & $0.100^{*}$ & \\
\hline C51 & $1.1575(7)$ & $0.1517(7)$ & $0.5798(6)$ & $0.086(3)$ & \\
\hline H51 & 1.208629 & 0.154018 & 0.612192 & $0.104^{*}$ & \\
\hline C61 & $1.0564(6)$ & $0.1865(6)$ & $0.6168(5)$ & 0.0663 (19) & \\
\hline H61 & 1.038097 & 0.213381 & 0.673411 & $0.080 *$ & \\
\hline C71 & $0.9836(5)$ & $0.1804(5)$ & $0.5678(4)$ & $0.0508(15)$ & \\
\hline $\mathrm{S} 12$ & $0.90767(14)$ & $0.45315(14)$ & $0.35417(13)$ & $0.0613(5)$ & \\
\hline S22 & $0.62518(13)$ & $0.40188(13)$ & $0.36506(14)$ & $0.0599(4)$ & \\
\hline $\mathrm{O} 12$ & $0.9364(4)$ & $0.5197(5)$ & $0.2777(4)$ & $0.0888(17)$ & \\
\hline $\mathrm{O} 22$ & $0.9875(4)$ & $0.3742(4)$ & $0.3914(4)$ & $0.0771(15)$ & \\
\hline N12 & $0.8226(4)$ & $0.4027(4)$ & $0.3260(4)$ & $0.0542(13)$ & \\
\hline $\mathrm{C} 12$ & $0.7336(5)$ & $0.4323(5)$ & $0.3765(4)$ & $0.0547(16)$ & \\
\hline $\mathrm{C} 22$ & $0.7294(5)$ & $0.5008(5)$ & $0.4466(5)$ & $0.0561(16)$ & \\
\hline C32 & $0.6476(6)$ & $0.5427(6)$ & $0.5116(6)$ & $0.073(2)$ & \\
\hline H32 & 0.583357 & 0.532327 & 0.514579 & $0.087^{*}$ & \\
\hline $\mathrm{C} 42$ & $0.6658(8)$ & $0.6011(7)$ & $0.5723(7)$ & 0.099 & \\
\hline $\mathrm{H} 42$ & 0.613532 & 0.627817 & 0.618554 & $0.118^{*}$ & \\
\hline C52 & $0.7595(9)$ & $0.6196(7)$ & $0.5647(8)$ & $0.101(3)$ & \\
\hline H52 & 0.768754 & 0.660994 & 0.604262 & $0.121 *$ & \\
\hline C62 & $0.8403(7)$ & $0.5784(6)$ & $0.5000(6)$ & $0.081(2)$ & \\
\hline H62 & 0.904173 & 0.590096 & 0.495595 & $0.097^{*}$ & \\
\hline
\end{tabular}
(isotropic) treatment of cell esds is used for estimating esds involving 1.s. planes.

Fractional atomic coordinates and isotropic or equivalent isotropic displacement parameters $\left(\AA^{2}\right)$ 


\begin{tabular}{|c|c|c|c|c|}
\hline $\mathrm{C} 72$ & $0.8223(6)$ & $0.5191(5)$ & $0.4420(5)$ & $0.0603(17)$ \\
\hline $\mathrm{S} 13$ & $0.77183(17)$ & $-0.04495(15)$ & $0.14420(12)$ & $0.0661(5)$ \\
\hline $\mathrm{S} 23$ & $0.79677(17)$ & $0.24580(16)$ & $0.09670(13)$ & $0.0706(5)$ \\
\hline $\mathrm{O} 13$ & $0.6707(5)$ & $-0.0539(5)$ & $0.1495(4)$ & $0.0920(18)$ \\
\hline $\mathrm{O} 23$ & $0.8391(6)$ & $-0.1206(5)$ & 0.1963 (4) & $0.099(2)$ \\
\hline N13 & $0.7665(5)$ & $0.0683(4)$ & $0.1702(4)$ & $0.0658(16)$ \\
\hline $\mathrm{C} 13$ & $0.8007(6)$ & $0.1233(6)$ & $0.0992(4)$ & $0.0605(18)$ \\
\hline $\mathrm{C} 23$ & $0.8414(5)$ & $0.0700(6)$ & $0.0148(4)$ & $0.0565(17)$ \\
\hline C33 & $0.8920(6)$ & $0.1030(6)$ & $-0.0706(5)$ & $0.072(2)$ \\
\hline H33 & 0.903369 & 0.166448 & -0.082209 & $0.086^{*}$ \\
\hline $\mathrm{C} 43$ & $0.9246(6)$ & $0.0342(7)$ & $-0.1378(5)$ & $0.078(2)$ \\
\hline $\mathrm{H} 43$ & 0.958826 & 0.053267 & -0.195180 & $0.094^{*}$ \\
\hline C53 & 0.9087 (6) & $-0.0566(7)$ & $-0.1227(6)$ & $0.080(2)$ \\
\hline H53 & 0.929421 & -0.097954 & -0.170315 & $0.096^{*}$ \\
\hline C63 & $0.8618(6)$ & $-0.0909(6)$ & $-0.0375(5)$ & $0.0645(18)$ \\
\hline H63 & 0.852797 & -0.155356 & -0.026103 & $0.077^{*}$ \\
\hline C73 & $0.8295(5)$ & $-0.0260(5)$ & $0.0287(4)$ & $0.0566(16)$ \\
\hline S14 & $0.4768(3)$ & $0.2283(3)$ & $0.1562(4)$ & 0.1564 (19) \\
\hline $\mathrm{S} 24$ & $0.58604(17)$ & $0.09204(16)$ & $0.40010(14)$ & $0.0744(6)$ \\
\hline $\mathrm{O} 14$ & $0.5430(12)$ & $0.2127(11)$ & $0.0714(8)$ & $0.224(8)$ \\
\hline $\mathrm{O} 24$ & $0.4002(9)$ & $0.3222(7)$ & $0.1609(11)$ & $0.239(8)$ \\
\hline N14 & $0.5432(5)$ & $0.2110(5)$ & $0.2431(6)$ & $0.093(2)$ \\
\hline $\mathrm{C} 14$ & $0.5281(5)$ & $0.1352(5)$ & $0.3060(6)$ & $0.070(2)$ \\
\hline $\mathrm{C} 24$ & $0.4566(6)$ & $0.0842(6)$ & $0.2798(8)$ & $0.084(3)$ \\
\hline C34 & $0.4227(6)$ & $0.0062(7)$ & $0.3280(8)$ & $0.098(3)$ \\
\hline H34 & 0.443561 & -0.021910 & 0.385174 & $0.117^{*}$ \\
\hline $\mathrm{C} 44$ & $0.3593(8)$ & $-0.0302(9)$ & $0.2928(12)$ & $0.139(5)$ \\
\hline H44 & 0.334741 & -0.082728 & 0.326089 & $0.167^{*}$ \\
\hline C54 & $0.3305(11)$ & $0.0102(10)$ & $0.2072(14)$ & $0.191(9)$ \\
\hline H54 & 0.290155 & -0.018167 & 0.181236 & $0.230^{*}$ \\
\hline C64 & $0.3598(11)$ & $0.0901(10)$ & 0.1607 (14) & $0.194(9)$ \\
\hline H64 & 0.338601 & 0.119274 & 0.103853 & $0.233^{*}$ \\
\hline C74 & $0.4222(8)$ & $0.1268(8)$ & $0.2002(10)$ & $0.116(4)$ \\
\hline N15 & $0.5352(5)$ & $0.2612(5)$ & $0.5904(5)$ & 0.0738 \\
\hline N25 & $0.0154(5)$ & $0.3171(4)$ & $1.1297(4)$ & $0.0636(15)$ \\
\hline $\mathrm{C} 15$ & $0.5497(6)$ & $0.3145(6)$ & $0.6487(6)$ & $0.081(2)$ \\
\hline H15 & 0.606869 & 0.339695 & 0.635095 & $0.097 *$ \\
\hline $\mathrm{C} 25$ & $0.4839(7)$ & $0.3354(7)$ & $0.7301(7)$ & $0.102(3)$ \\
\hline $\mathrm{H} 25$ & 0.497345 & 0.375572 & 0.768450 & $0.122 *$ \\
\hline $\mathrm{C} 35$ & $0.4003(9)$ & $0.2993(8)$ & $0.7563(7)$ & $0.117(2)$ \\
\hline $\mathrm{C} 45$ & $0.3833(7)$ & $0.2470(7)$ & 0.6937 (7) & 0.099 (3) \\
\hline $\mathrm{H} 45$ & 0.325658 & 0.222573 & 0.705694 & $0.118^{*}$ \\
\hline $\mathrm{C} 55$ & $0.4503(6)$ & $0.2293(6)$ & $0.6120(6)$ & $0.081(2)$ \\
\hline H55 & 0.435691 & 0.193616 & 0.570298 & $0.097^{*}$ \\
\hline C65 & $0.0985(6)$ & $0.3269(7)$ & $1.1586(6)$ & $0.084(2)$ \\
\hline H65 & 0.107427 & 0.305888 & 1.220409 & $0.101^{*}$ \\
\hline $\mathrm{C} 75$ & $0.1716(6)$ & $0.3668(7)$ & $1.1009(8)$ & $0.101(3)$ \\
\hline H75 & 0.227885 & 0.371349 & 1.124832 & $0.121^{*}$ \\
\hline
\end{tabular}




\begin{tabular}{|c|c|c|c|c|c|}
\hline $\mathrm{C} 85$ & $0.1632(8)$ & $0.3997(7)$ & $1.0092(8)$ & $0.108(2)$ & \\
\hline C95 & $0.0806(6)$ & $0.3843(6)$ & $0.9810(6)$ & $0.077(2)$ & \\
\hline H95 & 0.072422 & 0.400772 & 0.918608 & $0.092 *$ & \\
\hline C105 & $0.0090(6)$ & $0.3457(5)$ & $1.0403(5)$ & 0.0659 (19) & \\
\hline H105 & -0.046711 & 0.339131 & 1.016770 & $0.079 *$ & \\
\hline C115 & $0.3344(8)$ & $0.3133(6)$ & $0.8456(7)$ & $0.119(2)$ & \\
\hline H11A & 0.281135 & 0.279603 & 0.849357 & $0.143^{*}$ & \\
\hline H11B & 0.375009 & 0.280774 & 0.894774 & $0.143^{*}$ & \\
\hline C125 & $0.2860(8)$ & $0.4175(6)$ & $0.8625(7)$ & $0.117(2)$ & \\
\hline $\mathrm{H} 12 \mathrm{~A}$ & 0.234327 & 0.443215 & 0.821442 & $0.140^{*}$ & \\
\hline H12B & 0.337977 & 0.453345 & 0.840643 & $0.140^{*}$ & \\
\hline C135 & $0.2371(8)$ & $0.4496(7)$ & $0.9533(6)$ & $0.113(2)$ & \\
\hline $\mathrm{H} 13 \mathrm{~A}$ & 0.202733 & 0.520722 & 0.944030 & $0.135^{*}$ & \\
\hline H13B & 0.291114 & 0.442577 & 0.989975 & $0.135^{*}$ & \\
\hline S1A & $0.6847(8)$ & $0.4079(6)$ & $0.8253(6)$ & $0.133(3)$ & $0.328(5)$ \\
\hline O1A & $0.6320(12)$ & $0.4694(10)$ & $0.9058(11)$ & $0.186(9)$ & $0.328(5)$ \\
\hline $\mathrm{C} 1 \mathrm{~A}$ & $0.8110(12)$ & $0.4169(19)$ & $0.7950(17)$ & $0.22(2)$ & $0.328(5)$ \\
\hline H1A & 0.844439 & 0.378155 & 0.744136 & $0.330^{*}$ & $0.328(5)$ \\
\hline H1B & 0.810526 & 0.485971 & 0.776836 & $0.330^{*}$ & $0.328(5)$ \\
\hline $\mathrm{H} 1 \mathrm{C}$ & 0.847147 & 0.391445 & 0.847388 & $0.330^{*}$ & $0.328(5)$ \\
\hline $\mathrm{C} 2 \mathrm{~A}$ & $0.6862(17)$ & $0.2819(7)$ & 0.8598 (14) & $0.127(8)$ & $0.328(5)$ \\
\hline $\mathrm{H} 2 \mathrm{~A}$ & 0.719371 & 0.242681 & 0.809211 & $0.191^{*}$ & $0.328(5)$ \\
\hline $\mathrm{H} 2 \mathrm{~B}$ & 0.722893 & 0.257230 & 0.911939 & $0.191^{*}$ & $0.328(5)$ \\
\hline $\mathrm{H} 2 \mathrm{C}$ & 0.617077 & 0.276749 & 0.877144 & $0.191^{*}$ & $0.328(5)$ \\
\hline S1B & $0.7251(11)$ & $0.3810(9)$ & $0.8874(12)$ & 0.133 & $0.172(5)$ \\
\hline O1B & $0.6320(12)$ & $0.4694(10)$ & $0.9058(11)$ & $0.186(9)$ & $0.172(5)$ \\
\hline $\mathrm{C} 1 \mathrm{~B}$ & $0.8110(12)$ & $0.4169(19)$ & $0.7950(17)$ & $0.22(2)$ & $0.172(5)$ \\
\hline H1D & 0.869773 & 0.360862 & 0.783539 & $0.330^{*}$ & $0.172(5)$ \\
\hline $\mathrm{H} 1 \mathrm{E}$ & 0.778031 & 0.438247 & 0.740327 & $0.330^{*}$ & $0.172(5)$ \\
\hline $\mathrm{H} 1 \mathrm{~F}$ & 0.832267 & 0.471290 & 0.810252 & $0.330^{*}$ & $0.172(5)$ \\
\hline $\mathrm{C} 2 \mathrm{~B}$ & $0.6862(17)$ & $0.2819(7)$ & $0.8598(14)$ & $0.127(8)$ & $0.172(5)$ \\
\hline $\mathrm{H} 2 \mathrm{D}$ & 0.744977 & 0.225914 & 0.848166 & $0.191^{*}$ & $0.172(5)$ \\
\hline $\mathrm{H} 2 \mathrm{E}$ & 0.639151 & 0.262109 & 0.910763 & $0.191^{*}$ & $0.172(5)$ \\
\hline $\mathrm{H} 2 \mathrm{~F}$ & 0.653021 & 0.303303 & 0.805264 & $0.191^{*}$ & $0.172(5)$ \\
\hline $\mathrm{O} 1 \mathrm{~W}$ & $0.5624(10)$ & $0.4406(7)$ & $0.1121(8)$ & $0.184(5)$ & \\
\hline H1WA & $0.523(13)$ & $0.505(4)$ & $0.088(12)$ & $0.275^{*}$ & \\
\hline H1WB & $0.550(3)$ & $0.395(8)$ & $0.077(8)$ & $0.275^{*}$ & \\
\hline
\end{tabular}

Atomic displacement parameters $\left(\AA^{2}\right)$

\begin{tabular}{lllllll}
\hline & $U^{11}$ & $U^{22}$ & $U^{33}$ & $U^{12}$ & $U^{13}$ & $U^{23}$ \\
\hline $\mathrm{Ag} 1$ & $0.0633(4)$ & $0.0866(4)$ & $0.0619(4)$ & $-0.0244(3)$ & $0.0095(3)$ & $-0.0088(3)$ \\
$\mathrm{Ag} 2$ & $0.0624(3)$ & $0.0821(4)$ & $0.0466(3)$ & $-0.0265(3)$ & $0.0027(2)$ & $-0.0102(3)$ \\
$\mathrm{Ag} 3$ & $0.0698(4)$ & $0.0936(4)$ & $0.0426(3)$ & $-0.0252(3)$ & $-0.0023(3)$ & $-0.0107(3)$ \\
$\mathrm{Ag} 4$ & $0.0654(4)$ & $0.0731(4)$ & $0.0835(4)$ & $-0.0293(3)$ & $-0.0065(3)$ & $-0.0152(3)$ \\
$\mathrm{S} 11$ & $0.0542(10)$ & $0.0723(11)$ & $0.0373(8)$ & $-0.0190(8)$ & $-0.0006(7)$ & $-0.0047(7)$ \\
$\mathrm{S} 21$ & $0.0628(11)$ & $0.0771(11)$ & $0.0354(8)$ & $-0.0121(9)$ & $0.0025(7)$ & $-0.0081(8)$ \\
$\mathrm{O} 11$ & $0.070(3)$ & $0.098(4)$ & $0.042(3)$ & $-0.038(3)$ & $-0.003(2)$ & $0.003(2)$
\end{tabular}




\begin{tabular}{|c|c|c|c|c|c|c|}
\hline $\mathrm{O} 21$ & $0.072(3)$ & $0.074(3)$ & $0.071(3)$ & $-0.004(3)$ & $-0.004(3)$ & $-0.021(3)$ \\
\hline N11 & $0.051(3)$ & $0.074(4)$ & $0.037(3)$ & $-0.007(3)$ & -0.007 (2) & $-0.005(2)$ \\
\hline C11 & 0.049 (4) & 0.069 (4) & 0.039 (3) & $-0.016(3)$ & -0.006 & $0.006(3)$ \\
\hline $\mathrm{C} 21$ & $0.054(4)$ & $0.052(3)$ & $0.042(3)$ & $-0.015(3)$ & -0.002 & $0.006(3)$ \\
\hline $\mathrm{C} 31$ & $0.052(4)$ & 0.095 & $0.052(4)$ & -0.013 & $0.001(3)$ & $-0.004(4)$ \\
\hline $\mathrm{C} 41$ & $0.053(5)$ & $0.128(7)$ & $0.063(5)$ & $-0.024(5)$ & -0.009 & $0.009(5)$ \\
\hline C51 & $0.061(5)$ & $0.123(7)$ & $0.079(6)$ & $-0.035(5)$ & $-0.024(5)$ & $0.012(5)$ \\
\hline C61 & $0.073(5)$ & $0.077(5)$ & $0.052(4)$ & -0.028 & -0.018 & 0.009 (3) \\
\hline C71 & $0.050(4)$ & $0.060(4)$ & $0.043(3)$ & -0.020 & -0.009 & 0.007 (3) \\
\hline S12 & $0.0549(10)$ & $0.0743(11)$ & $0.0622(11)$ & $-0.0306(9)$ & $-0.0107(8)$ & $-0.0019(9)$ \\
\hline S22 & $0.0451(9)$ & $0.0628(10)$ & $0.0737(12)$ & $-0.0176(8)$ & $-0.0049(8)$ & $-0.0112(9)$ \\
\hline $\mathrm{O} 12$ & $0.079(4)$ & 0.109 (4) & $0.090(4)$ & -0.059 & -0.010 & $0.012(3)$ \\
\hline $\mathrm{O} 22$ & $0.057(3)$ & $0.088(4)$ & $0.087(4)$ & -0.015 & $-0.016(3)$ & $-0.013(3)$ \\
\hline $\mathrm{N} 12$ & $0.047(3)$ & 0.060 & $0.058(3)$ & -0.020 & -0.001 & $-0.012(3)$ \\
\hline $\mathrm{C} 12$ & $0.062(4)$ & $0.060(4)$ & $0.047(4)$ & $-0.027(3)$ & -0.009 & $0.002(3)$ \\
\hline $\mathrm{C} 22$ & $0.055(4)$ & $0.052(4)$ & $0.060(4)$ & -0.010 & $-0.014(3)$ & $-0.004(3)$ \\
\hline C32 & $0.054(4)$ & $0.079(5)$ & $0.083(5)$ & $-0.004(4)$ & -0.014 & $-0.024(4)$ \\
\hline $\mathrm{C} 42$ & $0.095(7)$ & $0.094(6)$ & $0.104(7)$ & $-0.003(6)$ & $-0.017(6)$ & $-0.042(6)$ \\
\hline C52 & $0.105(8)$ & $0.083(6)$ & $0.127(9)$ & $-0.011(6)$ & $-0.034(7)$ & $-0.053(6)$ \\
\hline C62 & $0.091(6)$ & $0.074(5)$ & $0.092(6)$ & -0.028 & $-0.031(5)$ & $-0.015(5)$ \\
\hline C72 & $0.064(5)$ & $0.058(4)$ & $0.063(4)$ & -0.018 & $-0.022(4)$ & $-0.003(3)$ \\
\hline S13 & $0.0841(14)$ & $0.0762(12)$ & $0.0419(9)$ & $-0.0343(11)$ & $-0.0004(9)$ & $-0.0039(8)$ \\
\hline S23 & $0.0935(15)$ & $0.0871(13)$ & $0.0480(10)$ & $-0.0530(12)$ & $-0.0116(10)$ & $-0.0007(9)$ \\
\hline O13 & $0.088(4)$ & $0.102(4)$ & $0.093(4)$ & $-0.051(3)$ & $0.019(3)$ & $-0.018(3)$ \\
\hline $\mathrm{O} 23$ & $0.138(6)$ & $0.094(4)$ & $0.060(3)$ & $-0.027(4)$ & $-0.029(4)$ & $0.015(3)$ \\
\hline N13 & $0.090(5)$ & $0.080(4)$ & $0.035(3)$ & $-0.042(3)$ & $0.003(3)$ & $-0.007(3)$ \\
\hline $\mathrm{C} 13$ & $0.072(5)$ & $0.091(5)$ & $0.034(3)$ & $-0.045(4)$ & $-0.009(3)$ & $-0.006(3)$ \\
\hline $\mathrm{C} 23$ & $0.050(4)$ & $0.094(5)$ & $0.031(3)$ & $-0.027(4)$ & $-0.009(3)$ & $-0.002(3)$ \\
\hline C33 & $0.070(5)$ & $0.099(6)$ & $0.049(4)$ & $-0.040(4)$ & $-0.001(4)$ & $0.006(4)$ \\
\hline $\mathrm{C} 43$ & $0.076(5)$ & $0.120(7)$ & $0.032(4)$ & $-0.027(5)$ & $0.007(3)$ & $-0.005(4)$ \\
\hline C53 & $0.076(6)$ & $0.104(7)$ & $0.055(5)$ & $-0.019(5)$ & 0.000 & -0.015 (4) \\
\hline C63 & $0.066(5)$ & $0.075(5)$ & $0.049(4)$ & $-0.009(4)$ & $-0.009(3)$ & $-0.013(3)$ \\
\hline $\mathrm{C} 73$ & $0.056(4)$ & $0.072(4)$ & $0.042(4)$ & $-0.019(3)$ & $-0.010(3)$ & $0.000(3)$ \\
\hline S14 & $0.156(3)$ & $0.136(3)$ & $0.223(4)$ & $-0.100(3)$ & $-0.140(3)$ & $0.094(3)$ \\
\hline S24 & $0.0768(13)$ & $0.0880(13)$ & $0.0605(11)$ & $-0.0384(11)$ & $0.0086(10)$ & $-0.0054(10)$ \\
\hline $\mathrm{O} 14$ & $0.323(17)$ & $0.298(15)$ & $0.148(9)$ & $-0.224(14)$ & $-0.170(11)$ & $0.113(10)$ \\
\hline $\mathrm{O} 24$ & $0.176(10)$ & $0.115(6)$ & $0.46(2)$ & $-0.062(7)$ & $-0.210(13)$ & $0.117(9)$ \\
\hline N14 & $0.080(5)$ & $0.084(4)$ & $0.128(6)$ & $-0.045(4)$ & $-0.052(5)$ & $0.035(4)$ \\
\hline C14 & $0.049(4)$ & $0.053(4)$ & $0.103(6)$ & $-0.015(3)$ & $0.004(4)$ & $-0.011(4)$ \\
\hline $\mathrm{C} 24$ & $0.049(4)$ & $0.063(5)$ & $0.139(8)$ & $-0.020(4)$ & $-0.011(5)$ & $-0.004(5)$ \\
\hline C34 & $0.054(5)$ & $0.082(6)$ & $0.162(10)$ & $-0.037(4)$ & $-0.003(5)$ & $-0.003(6)$ \\
\hline $\mathrm{C} 44$ & $0.082(7)$ & $0.101(8)$ & $0.245(17)$ & $-0.049(6)$ & $-0.049(9)$ & $0.024(9)$ \\
\hline $\mathrm{C} 54$ & $0.162(13)$ & $0.130(10)$ & $0.34(2)$ & $-0.101(10)$ & $-0.171(16)$ & 0.085 (13) \\
\hline C64 & $0.173(13)$ & $0.129(10)$ & $0.34(2)$ & $-0.090(10)$ & $-0.191(15)$ & $0.083(12)$ \\
\hline C74 & $0.087(7)$ & $0.102(7)$ & 0.180 & $-0.051(6)$ & $-0.069(8)$ & $0.033(7)$ \\
\hline N15 & $0.054(4)$ & $0.089(4)$ & $0.072(4)$ & $-0.022(3)$ & $0.015(3)$ & $-0.012(4)$ \\
\hline $\mathrm{N} 25$ & $0.058(4)$ & 0.079 (4) & $0.053(3)$ & $-0.024(3)$ & $0.006(3)$ & -0.010 \\
\hline $\mathrm{C} 15$ & $0.059(5)$ & $0.083(5)$ & $0.093(6)$ & $-0.017(4)$ & $0.014(4)$ & $-0.020(5)$ \\
\hline
\end{tabular}




\begin{tabular}{lllllll} 
& & & & & \\
C25 & $0.095(7)$ & $0.094(6)$ & $0.112(8)$ & $-0.035(5)$ & $0.040(6)$ & $-0.048(6)$ \\
C35 & $0.114(4)$ & $0.100(4)$ & $0.124(4)$ & $-0.051(3)$ & $0.066(4)$ & $-0.033(3)$ \\
C45 & $0.076(6)$ & $0.093(6)$ & $0.113(8)$ & $-0.033(5)$ & $0.036(5)$ & $-0.009(6)$ \\
C55 & $0.069(5)$ & $0.093(6)$ & $0.072(5)$ & $-0.019(5)$ & $0.005(4)$ & $-0.006(4)$ \\
C65 & $0.063(5)$ & $0.125(7)$ & $0.068(5)$ & $-0.030(5)$ & $-0.006(4)$ & $-0.018(5)$ \\
C75 & $0.037(4)$ & $0.118(7)$ & $0.148(10)$ & $-0.031(5)$ & $0.022(5)$ & $-0.037(7)$ \\
C85 & $0.103(4)$ & $0.096(4)$ & $0.120(4)$ & $-0.053(3)$ & $0.062(4)$ & $-0.039(3)$ \\
C95 & $0.074(5)$ & $0.077(5)$ & $0.067(5)$ & $-0.023(4)$ & $0.025(4)$ & $-0.007(4)$ \\
C105 & $0.057(4)$ & $0.071(4)$ & $0.068(5)$ & $-0.020(4)$ & $0.005(4)$ & $-0.011(4)$ \\
C115 & $0.116(4)$ & $0.103(3)$ & $0.126(4)$ & $-0.051(3)$ & $0.066(3)$ & $-0.032(3)$ \\
C125 & $0.113(4)$ & $0.102(3)$ & $0.125(4)$ & $-0.052(3)$ & $0.064(3)$ & $-0.033(3)$ \\
C135 & $0.107(4)$ & $0.100(3)$ & $0.123(4)$ & $-0.053(3)$ & $0.062(3)$ & $-0.036(3)$ \\
S1A & $0.193(10)$ & $0.098(5)$ & $0.105(7)$ & $-0.011(6)$ & $-0.056(6)$ & $-0.015(5)$ \\
O1A & $0.19(2)$ & $0.145(15)$ & $0.19(2)$ & $0.001(14)$ & $0.008(16)$ & $-0.073(14)$ \\
C1A & $0.20(3)$ & $0.22(3)$ & $0.30(4)$ & $-0.13(3)$ & $0.07(3)$ & $-0.21(3)$ \\
C2A & $0.14(2)$ & $0.123(17)$ & $0.103(16)$ & $0.016(15)$ & $-0.065(15)$ & $-0.003(13)$ \\
S1B & $0.193(10)$ & $0.098(5)$ & $0.105(7)$ & $-0.011(6)$ & $-0.056(6)$ & $-0.015(5)$ \\
O1B & $0.19(2)$ & $0.145(15)$ & $0.19(2)$ & $0.001(14)$ & $0.008(16)$ & $-0.073(14)$ \\
C1B & $0.20(3)$ & $0.22(3)$ & $0.30(4)$ & $-0.13(3)$ & $0.07(3)$ & $-0.21(3)$ \\
C2B & $0.14(2)$ & $0.123(17)$ & $0.103(16)$ & $0.016(15)$ & $-0.065(15)$ & $-0.003(13)$ \\
O1W & $0.231(12)$ & $0.141(7)$ & $0.220(11)$ & $-0.094(8)$ & $-0.116(9)$ & $0.041(7)$ \\
& & & & & & \\
\hline
\end{tabular}

Geometric parameters $\left(\mathcal{A},{ }^{o}\right)$

\begin{tabular}{llll}
\hline $\mathrm{Ag} 1-\mathrm{N} 15$ & $2.307(6)$ & $\mathrm{C} 63-\mathrm{H} 63$ & 0.9300 \\
$\mathrm{Ag} 1-\mathrm{N} 11$ & $2.422(5)$ & $\mathrm{S} 14-\mathrm{O} 14$ & $1.411(15)$ \\
$\mathrm{Ag} 1-\mathrm{S} 22$ & $2.607(2)$ & $\mathrm{S} 14-\mathrm{O} 24$ & $1.429(12)$ \\
$\mathrm{Ag} 1-\mathrm{S} 24$ & $2.647(2)$ & $\mathrm{S} 14-\mathrm{N} 14$ & $1.653(8)$ \\
$\mathrm{Ag} 1-\mathrm{Ag} 3$ & $2.8307(8)$ & $\mathrm{S} 14-\mathrm{C} 74$ & $1.776(10)$ \\
$\mathrm{Ag} 2-\mathrm{N} 12$ & $2.320(5)$ & $\mathrm{S} 24-\mathrm{C} 14$ & $1.668(9)$ \\
$\mathrm{Ag} 2-\mathrm{N} 25^{\mathrm{i}}$ & $2.335(6)$ & $\mathrm{N} 14-\mathrm{C} 14$ & $1.333(10)$ \\
$\mathrm{Ag} 2-\mathrm{S} 23$ & $2.606(2)$ & $\mathrm{C} 14-\mathrm{C} 24$ & $1.502(11)$ \\
$\mathrm{Ag} 2-\mathrm{S} 21$ & $2.615(2)$ & $\mathrm{C} 24-\mathrm{C} 74$ & $1.331(14)$ \\
$\mathrm{Ag} 2-\mathrm{Ag} 4$ & $2.9180(8)$ & $\mathrm{C} 24-\mathrm{C} 34$ & $1.359(11)$ \\
$\mathrm{Ag} 2-\mathrm{Ag} 3$ & $3.3489(8)$ & $\mathrm{C} 34-\mathrm{C} 44$ & $1.340(14)$ \\
$\mathrm{Ag} 3-\mathrm{N} 13$ & $2.317(5)$ & $\mathrm{C} 34-\mathrm{H} 34$ & 0.9300 \\
$\mathrm{Ag} 3-\mathrm{S} 21$ & $2.416(2)$ & $\mathrm{C} 44-\mathrm{C} 54$ & $1.376(19)$ \\
$\mathrm{Ag} 3-\mathrm{S} 24$ & $2.472(2)$ & $\mathrm{C} 44-\mathrm{H} 44$ & 0.9300 \\
$\mathrm{Ag} 3-\mathrm{Ag} 4$ & $3.0692(9)$ & $\mathrm{C} 54-\mathrm{C} 64$ & $1.343(17)$ \\
$\mathrm{Ag} 4-\mathrm{N} 14$ & $2.354(6)$ & $\mathrm{C} 54-\mathrm{H} 54$ & 0.9300 \\
$\mathrm{Ag} 4-\mathrm{S} 22$ & $2.461(2)$ & $\mathrm{C} 64-\mathrm{C} 74$ & $1.367(15)$ \\
$\mathrm{Ag} 4-\mathrm{S} 23$ & $2.510(2)$ & $\mathrm{C} 64-\mathrm{H} 64$ & 1.9300 \\
$\mathrm{Ag} 4-\mathrm{O} 1 \mathrm{~W}$ & $2.612(9)$ & $\mathrm{N} 15-\mathrm{C} 15$ & $1.337(10)$ \\
$\mathrm{S} 11-\mathrm{O} 11$ & $1.418(5)$ & $\mathrm{N} 15-\mathrm{C} 55$ & $1.325(9)$ \\
$\mathrm{S} 11-\mathrm{O} 21$ & $1.421(5)$ & $\mathrm{N} 25-\mathrm{C} 105$ & $1.340(10)$ \\
$\mathrm{S} 11-\mathrm{N} 11$ & $1.665(6)$ & $\mathrm{N} 25-\mathrm{C} 65$ & $1.379(11)$ \\
$\mathrm{S} 11-\mathrm{C} 71$ & $1.751(7)$ & $\mathrm{C} 15-\mathrm{C} 25$ & 0.9300 \\
$\mathrm{~S} 21-\mathrm{C} 11$ & $1.714(7)$ & $\mathrm{C} 15-\mathrm{H} 15$ & \\
& & &
\end{tabular}




\begin{tabular}{|c|c|c|c|}
\hline $\mathrm{N} 11-\mathrm{C} 11$ & $1.319(8)$ & $\mathrm{C} 25-\mathrm{C} 35$ & $1.358(13)$ \\
\hline $\mathrm{C} 11-\mathrm{C} 21$ & $1.470(9)$ & $\mathrm{C} 25-\mathrm{H} 25$ & 0.9300 \\
\hline $\mathrm{C} 21-\mathrm{C} 71$ & $1.379(9)$ & $\mathrm{C} 35-\mathrm{C} 45$ & $1.351(14)$ \\
\hline $\mathrm{C} 21-\mathrm{C} 31$ & $1.393(9)$ & $\mathrm{C} 35-\mathrm{C} 115$ & $1.460(6)$ \\
\hline $\mathrm{C} 31-\mathrm{C} 41$ & $1.355(11)$ & $\mathrm{C} 45-\mathrm{C} 55$ & $1.384(11)$ \\
\hline C31-H31 & 0.9300 & $\mathrm{C} 45-\mathrm{H} 45$ & 0.9300 \\
\hline $\mathrm{C} 41-\mathrm{C} 51$ & $1.364(12)$ & $\mathrm{C} 55-\mathrm{H} 55$ & 0.9300 \\
\hline $\mathrm{C} 41-\mathrm{H} 41$ & 0.9300 & $\mathrm{C} 65-\mathrm{C} 75$ & $1.384(12)$ \\
\hline $\mathrm{C} 51-\mathrm{C} 61$ & $1.373(11)$ & C65-H65 & 0.9300 \\
\hline C51-H51 & 0.9300 & $\mathrm{C} 75-\mathrm{C} 85$ & $1.370(15)$ \\
\hline C61-C71 & $1.365(9)$ & $\mathrm{C} 75-\mathrm{H} 75$ & 0.9300 \\
\hline C61-H61 & 0.9300 & $\mathrm{C} 85-\mathrm{C} 95$ & $1.362(14)$ \\
\hline $\mathrm{S} 12-\mathrm{O} 12$ & $1.420(6)$ & $\mathrm{C} 85-\mathrm{C} 135$ & $1.460(6)$ \\
\hline $\mathrm{S} 12-\mathrm{O} 22$ & $1.434(5)$ & $\mathrm{C} 95-\mathrm{C} 105$ & $1.369(10)$ \\
\hline $\mathrm{S} 12-\mathrm{N} 12$ & $1.670(6)$ & C95-H95 & 0.9300 \\
\hline $\mathrm{S} 12-\mathrm{C} 72$ & $1.759(8)$ & C105-H105 & 0.9300 \\
\hline $\mathrm{S} 22-\mathrm{C} 12$ & $1.709(7)$ & $\mathrm{C} 115-\mathrm{C} 125$ & $1.455(6)$ \\
\hline $\mathrm{N} 12-\mathrm{C} 12$ & $1.302(8)$ & C115-H11A & 0.9700 \\
\hline $\mathrm{C} 12-\mathrm{C} 22$ & $1.496(9)$ & C115-H11B & 0.9700 \\
\hline $\mathrm{C} 22-\mathrm{C} 72$ & $1.363(10)$ & $\mathrm{C} 125-\mathrm{C} 135$ & $1.457(6)$ \\
\hline $\mathrm{C} 22-\mathrm{C} 32$ & $1.387(10)$ & $\mathrm{C} 125-\mathrm{H} 12 \mathrm{~A}$ & 0.9700 \\
\hline $\mathrm{C} 32-\mathrm{C} 42$ & $1.399(12)$ & $\mathrm{C} 125-\mathrm{H} 12 \mathrm{~B}$ & 0.9700 \\
\hline C $32-\mathrm{H} 32$ & 0.9300 & $\mathrm{C} 135-\mathrm{H} 13 \mathrm{~A}$ & 0.9700 \\
\hline $\mathrm{C} 42-\mathrm{C} 52$ & $1.370(13)$ & C135-H13B & 0.9700 \\
\hline $\mathrm{C} 42-\mathrm{H} 42$ & 0.9300 & $\mathrm{~S} 1 \mathrm{~A}-\mathrm{O} 1 \mathrm{~A}$ & $1.520(3)$ \\
\hline $\mathrm{C} 52-\mathrm{C} 62$ & $1.374(13)$ & $\mathrm{S} 1 \mathrm{~A}-\mathrm{C} 1 \mathrm{~A}$ & $1.751(3)$ \\
\hline $\mathrm{C} 52-\mathrm{H} 52$ & 0.9300 & $\mathrm{~S} 1 \mathrm{~A}-\mathrm{C} 2 \mathrm{~A}$ & $1.752(3)$ \\
\hline $\mathrm{C} 62-\mathrm{C} 72$ & $1.376(10)$ & $\mathrm{C} 1 \mathrm{~A}-\mathrm{H} 1 \mathrm{~A}$ & 0.9600 \\
\hline $\mathrm{C} 62-\mathrm{H} 62$ & 0.9300 & $\mathrm{C} 1 \mathrm{~A}-\mathrm{H} 1 \mathrm{~B}$ & 0.9600 \\
\hline $\mathrm{S} 13-\mathrm{O} 23$ & $1.415(6)$ & $\mathrm{C} 1 \mathrm{~A}-\mathrm{H} 1 \mathrm{C}$ & 0.9600 \\
\hline $\mathrm{S} 13-\mathrm{O} 13$ & $1.421(6)$ & $\mathrm{C} 2 \mathrm{~A}-\mathrm{H} 2 \mathrm{~A}$ & 0.9600 \\
\hline $\mathrm{S} 13-\mathrm{N} 13$ & $1.664(6)$ & $\mathrm{C} 2 \mathrm{~A}-\mathrm{H} 2 \mathrm{~B}$ & 0.9600 \\
\hline $\mathrm{S} 13-\mathrm{C} 73$ & $1.756(7)$ & $\mathrm{C} 2 \mathrm{~A}-\mathrm{H} 2 \mathrm{C}$ & 0.9600 \\
\hline $\mathrm{S} 23-\mathrm{C} 13$ & $1.693(8)$ & $\mathrm{S} 1 \mathrm{~B}-\mathrm{O} 1 \mathrm{~B}$ & $1.517(3)$ \\
\hline $\mathrm{N} 13-\mathrm{C} 13$ & $1.300(8)$ & $\mathrm{S} 1 \mathrm{~B}-\mathrm{C} 1 \mathrm{~B}$ & $1.746(3)$ \\
\hline $\mathrm{C} 13-\mathrm{C} 23$ & $1.485(9)$ & $\mathrm{S} 1 \mathrm{~B}-\mathrm{C} 2 \mathrm{~B}$ & $1.749(3)$ \\
\hline $\mathrm{C} 23-\mathrm{C} 73$ & $1.379(10)$ & $\mathrm{C} 1 \mathrm{~B}-\mathrm{H} 1 \mathrm{D}$ & 0.9600 \\
\hline $\mathrm{C} 23-\mathrm{C} 33$ & $1.403(9)$ & $\mathrm{C} 1 \mathrm{~B}-\mathrm{H} 1 \mathrm{E}$ & 0.9600 \\
\hline $\mathrm{C} 33-\mathrm{C} 43$ & $1.409(11)$ & $\mathrm{C} 1 \mathrm{~B}-\mathrm{H} 1 \mathrm{~F}$ & 0.9600 \\
\hline C $33-\mathrm{H} 33$ & 0.9300 & $\mathrm{C} 2 \mathrm{~B}-\mathrm{H} 2 \mathrm{D}$ & 0.9600 \\
\hline $\mathrm{C} 43-\mathrm{C} 53$ & $1.330(11)$ & $\mathrm{C} 2 \mathrm{~B}-\mathrm{H} 2 \mathrm{E}$ & 0.9600 \\
\hline $\mathrm{C} 43-\mathrm{H} 43$ & 0.9300 & $\mathrm{C} 2 \mathrm{~B}-\mathrm{H} 2 \mathrm{~F}$ & 0.9600 \\
\hline $\mathrm{C} 53-\mathrm{C} 63$ & $1.384(10)$ & $\mathrm{O} 1 \mathrm{~W}-\mathrm{H} 1 \mathrm{WA}$ & $0.956(10)$ \\
\hline C53-H53 & 0.9300 & $\mathrm{O} 1 \mathrm{~W}-\mathrm{H} 1 \mathrm{WB}$ & $0.953(10)$ \\
\hline $\mathrm{C} 63-\mathrm{C} 73$ & $1.362(9)$ & & \\
\hline N15-Ag1-N11 & $111.9(2)$ & $\mathrm{C} 73-\mathrm{C} 23-\mathrm{C} 13$ & $112.0(6)$ \\
\hline N15-Ag1-S22 & $100.45(17)$ & $\mathrm{C} 33-\mathrm{C} 23-\mathrm{C} 13$ & $128.7(7)$ \\
\hline
\end{tabular}




\begin{tabular}{|c|c|}
\hline $\mathrm{N} 11-\mathrm{Ag} 1-\mathrm{S} 22$ & $105.35(14)$ \\
\hline N15-Ag1—S24 & $99.32(19)$ \\
\hline $\mathrm{N} 11-\mathrm{Ag} 1-\mathrm{S} 24$ & $121.61(14)$ \\
\hline $\mathrm{S} 22-\mathrm{Ag} 1-\mathrm{S} 24$ & $116.15(7)$ \\
\hline N15-Ag1-Ag3 & $150.49(18)$ \\
\hline N11-Ag1-Ag3 & $79.72(13)$ \\
\hline $\mathrm{S} 22-\mathrm{Ag} 1-\mathrm{Ag} 3$ & $102.32(5)$ \\
\hline S24-Ag1-Ag3 & $53.52(5)$ \\
\hline $\mathrm{N} 12-\mathrm{Ag} 2-\mathrm{N} 25^{\mathrm{i}}$ & $102.99(19)$ \\
\hline $\mathrm{N} 12-\mathrm{Ag} 2-\mathrm{S} 23$ & $127.40(15)$ \\
\hline $\mathrm{N} 25^{\mathrm{i}}-\mathrm{Ag} 2-\mathrm{S} 23$ & $92.24(16)$ \\
\hline $\mathrm{N} 12-\mathrm{Ag} 2-\mathrm{S} 21$ & $108.22(14)$ \\
\hline $\mathrm{N} 25^{\mathrm{i}}-\mathrm{Ag} 2-\mathrm{S} 21$ & $116.38(16)$ \\
\hline $\mathrm{S} 23-\mathrm{Ag} 2-\mathrm{S} 21$ & $109.02(6)$ \\
\hline $\mathrm{N} 12-\mathrm{Ag} 2-\mathrm{Ag} 4$ & $82.64(13)$ \\
\hline $\mathrm{N} 25^{\mathrm{i}}-\mathrm{Ag} 2-\mathrm{Ag} 4$ & $135.26(16)$ \\
\hline $\mathrm{S} 23-\mathrm{Ag} 2-\mathrm{Ag} 4$ & $53.68(5)$ \\
\hline $\mathrm{S} 21-\mathrm{Ag} 2-\mathrm{Ag} 4$ & $103.06(5)$ \\
\hline $\mathrm{N} 12-\mathrm{Ag} 2-\mathrm{Ag} 3$ & $107.90(13)$ \\
\hline $\mathrm{N} 25^{\mathrm{i}}-\mathrm{Ag} 2-\mathrm{Ag} 3$ & $148.13(15)$ \\
\hline S23-Ag2-Ag3 & $75.23(4)$ \\
\hline $\mathrm{S} 21-\mathrm{Ag} 2-\mathrm{Ag} 3$ & $45.78(5)$ \\
\hline $\mathrm{Ag} 4-\mathrm{Ag} 2-\mathrm{Ag} 3$ & $58.163(19)$ \\
\hline $\mathrm{N} 13-\mathrm{Ag} 3-\mathrm{S} 21$ & $106.92(16)$ \\
\hline $\mathrm{N} 13-\mathrm{Ag} 3-\mathrm{S} 24$ & $105.52(17)$ \\
\hline $\mathrm{S} 21-\mathrm{Ag} 3-\mathrm{S} 24$ & $147.31(7)$ \\
\hline N13-Ag3-Ag1 & $143.77(16)$ \\
\hline $\mathrm{S} 21-\mathrm{Ag} 3-\mathrm{Ag} 1$ & $95.14(5)$ \\
\hline S24-Ag3-Ag1 & $59.44(5)$ \\
\hline N13-Ag3-Ag4 & $76.88(15)$ \\
\hline $\mathrm{S} 21-\mathrm{Ag} 3-\mathrm{Ag} 4$ & $103.82(5)$ \\
\hline $\mathrm{S} 24-\mathrm{Ag} 3-\mathrm{Ag} 4$ & $87.29(6)$ \\
\hline $\mathrm{Ag} 1-\mathrm{Ag} 3-\mathrm{Ag} 4$ & $70.03(2)$ \\
\hline $\mathrm{N} 13-\mathrm{Ag} 3-\mathrm{Ag} 2$ & $85.74(14)$ \\
\hline $\mathrm{S} 21-\mathrm{Ag} 3-\mathrm{Ag} 2$ & $50.87(5)$ \\
\hline $\mathrm{S} 24-\mathrm{Ag} 3-\mathrm{Ag} 2$ & $136.51(6)$ \\
\hline Ag1-Ag3-Ag2 & $86.51(2)$ \\
\hline $\mathrm{Ag} 4-\mathrm{Ag} 3-\mathrm{Ag} 2$ & $53.872(18)$ \\
\hline N14-Ag4-S22 & $110.2(2)$ \\
\hline $\mathrm{N} 14-\mathrm{Ag} 4-\mathrm{S} 23$ & $105.5(2)$ \\
\hline $\mathrm{S} 22-\mathrm{Ag} 4-\mathrm{S} 23$ & $143.14(7)$ \\
\hline $\mathrm{N} 14-\mathrm{Ag} 4-\mathrm{O} 1 \mathrm{~W}$ & $90.5(3)$ \\
\hline $\mathrm{S} 22-\mathrm{Ag} 4-\mathrm{O} 1 \mathrm{~W}$ & $100.3(3)$ \\
\hline $\mathrm{S} 23-\mathrm{Ag} 4-\mathrm{O} 1 \mathrm{~W}$ & $88.2(3)$ \\
\hline N14-Ag4-Ag2 & $138.93(18)$ \\
\hline $\mathrm{S} 22-\mathrm{Ag} 4-\mathrm{Ag} 2$ & $89.29(5)$ \\
\hline $\mathrm{S} 23-\mathrm{Ag} 4-\mathrm{Ag} 2$ & $56.79(5)$ \\
\hline $\mathrm{O} 1 \mathrm{~W}-\mathrm{Ag} 4-\mathrm{Ag} 2$ & $122.1(3)$ \\
\hline
\end{tabular}

\begin{tabular}{|c|c|}
\hline $\mathrm{C} 23-\mathrm{C} 33-\mathrm{C} 43$ & $116.0(7)$ \\
\hline $\mathrm{C} 23-\mathrm{C} 33-\mathrm{H} 33$ & 122.0 \\
\hline $\mathrm{C} 43-\mathrm{C} 33-\mathrm{H} 33$ & 122.0 \\
\hline $\mathrm{C} 53-\mathrm{C} 43-\mathrm{C} 33$ & $122.9(7)$ \\
\hline $\mathrm{C} 53-\mathrm{C} 43-\mathrm{H} 43$ & 118.6 \\
\hline $\mathrm{C} 33-\mathrm{C} 43-\mathrm{H} 43$ & 118.6 \\
\hline $\mathrm{C} 43-\mathrm{C} 53-\mathrm{C} 63$ & $121.4(8)$ \\
\hline $\mathrm{C} 43-\mathrm{C} 53-\mathrm{H} 53$ & 119.3 \\
\hline $\mathrm{C} 63-\mathrm{C} 53-\mathrm{H} 53$ & 119.3 \\
\hline $\mathrm{C} 73-\mathrm{C} 63-\mathrm{C} 53$ & $116.9(8)$ \\
\hline $\mathrm{C} 73-\mathrm{C} 63-\mathrm{H} 63$ & 121.6 \\
\hline $\mathrm{C} 53-\mathrm{C} 63-\mathrm{H} 63$ & 121.6 \\
\hline $\mathrm{C} 63-\mathrm{C} 73-\mathrm{C} 23$ & $123.5(6)$ \\
\hline $\mathrm{C} 63-\mathrm{C} 73-\mathrm{S} 13$ & $129.4(6)$ \\
\hline $\mathrm{C} 23-\mathrm{C} 73-\mathrm{S} 13$ & $107.1(5)$ \\
\hline $\mathrm{O} 14-\mathrm{S} 14-\mathrm{O} 24$ & $117.3(8)$ \\
\hline $\mathrm{O} 14-\mathrm{S} 14-\mathrm{N} 14$ & $110.7(6)$ \\
\hline $\mathrm{O} 24-\mathrm{S} 14-\mathrm{N} 14$ & $108.5(7)$ \\
\hline $\mathrm{O} 14-\mathrm{S} 14-\mathrm{C} 74$ & $113.0(8)$ \\
\hline $\mathrm{O} 24-\mathrm{S} 14-\mathrm{C} 74$ & $110.7(7)$ \\
\hline $\mathrm{N} 14-\mathrm{S} 14-\mathrm{C} 74$ & $94.2(5)$ \\
\hline $\mathrm{C} 14-\mathrm{S} 24-\mathrm{Ag} 3$ & $96.3(3)$ \\
\hline $\mathrm{C} 14-\mathrm{S} 24-\mathrm{Ag} 1$ & $114.3(3)$ \\
\hline $\mathrm{Ag} 3-\mathrm{S} 24-\mathrm{Ag} 1$ & $67.04(6)$ \\
\hline $\mathrm{C} 14-\mathrm{N} 14-\mathrm{S} 14$ & $112.5(6)$ \\
\hline $\mathrm{C} 14-\mathrm{N} 14-\mathrm{Ag} 4$ & $129.5(6)$ \\
\hline $\mathrm{S} 14-\mathrm{N} 14-\mathrm{Ag} 4$ & $117.5(4)$ \\
\hline $\mathrm{N} 14-\mathrm{C} 14-\mathrm{C} 24$ & $112.3(8)$ \\
\hline $\mathrm{N} 14-\mathrm{C} 14-\mathrm{S} 24$ & $126.2(6)$ \\
\hline $\mathrm{C} 24-\mathrm{C} 14-\mathrm{S} 24$ & $121.4(6)$ \\
\hline $\mathrm{C} 74-\mathrm{C} 24-\mathrm{C} 34$ & $119.4(9)$ \\
\hline $\mathrm{C} 74-\mathrm{C} 24-\mathrm{C} 14$ & $112.3(8)$ \\
\hline $\mathrm{C} 34-\mathrm{C} 24-\mathrm{C} 14$ & $128.2(10)$ \\
\hline $\mathrm{C} 44-\mathrm{C} 34-\mathrm{C} 24$ & $119.7(12)$ \\
\hline $\mathrm{C} 44-\mathrm{C} 34-\mathrm{H} 34$ & 120.1 \\
\hline $\mathrm{C} 24-\mathrm{C} 34-\mathrm{H} 34$ & 120.1 \\
\hline $\mathrm{C} 34-\mathrm{C} 44-\mathrm{C} 54$ & $119.8(11)$ \\
\hline $\mathrm{C} 34-\mathrm{C} 44-\mathrm{H} 44$ & 120.1 \\
\hline $\mathrm{C} 54-\mathrm{C} 44-\mathrm{H} 44$ & 120.1 \\
\hline $\mathrm{C} 64-\mathrm{C} 54-\mathrm{C} 44$ & $121.0(12)$ \\
\hline C64-C54-H54 & 119.5 \\
\hline $\mathrm{C} 44-\mathrm{C} 54-\mathrm{H} 54$ & 119.5 \\
\hline $\mathrm{C} 54-\mathrm{C} 64-\mathrm{C} 74$ & $117.2(13)$ \\
\hline $\mathrm{C} 54-\mathrm{C} 64-\mathrm{H} 64$ & 121.4 \\
\hline $\mathrm{C} 74-\mathrm{C} 64-\mathrm{H} 64$ & 121.4 \\
\hline $\mathrm{C} 24-\mathrm{C} 74-\mathrm{C} 64$ & $122.5(10)$ \\
\hline $\mathrm{C} 24-\mathrm{C} 74-\mathrm{S} 14$ & $108.7(7)$ \\
\hline $\mathrm{C} 64-\mathrm{C} 74-\mathrm{S} 14$ & $128.6(10)$ \\
\hline
\end{tabular}




\begin{tabular}{|c|c|}
\hline $\mathrm{N} 14-\mathrm{Ag} 4-\mathrm{Ag} 3$ & $73.22(16)$ \\
\hline $\mathrm{S} 22-\mathrm{Ag} 4-\mathrm{Ag} 3$ & $99.45(5)$ \\
\hline $\mathrm{S} 23-\mathrm{Ag} 4-\mathrm{Ag} 3$ & $81.93(5)$ \\
\hline $\mathrm{O} 1 \mathrm{~W}-\mathrm{Ag} 4-\mathrm{Ag} 3$ & $157.8(2)$ \\
\hline $\mathrm{Ag} 2-\mathrm{Ag} 4-\mathrm{Ag} 3$ & $67.97(2)$ \\
\hline $\mathrm{O} 11-\mathrm{S} 11-\mathrm{O} 21$ & $117.6(3)$ \\
\hline $\mathrm{O} 11-\mathrm{S} 11-\mathrm{N} 11$ & $109.3(3)$ \\
\hline $\mathrm{O} 21-\mathrm{S} 11-\mathrm{N} 11$ & $108.5(3)$ \\
\hline $\mathrm{O} 11-\mathrm{S} 11-\mathrm{C} 71$ & $111.1(3)$ \\
\hline $\mathrm{O} 21-\mathrm{S} 11-\mathrm{C} 71$ & $112.3(3)$ \\
\hline $\mathrm{N} 11-\mathrm{S} 11-\mathrm{C} 71$ & $95.7(3)$ \\
\hline $\mathrm{C} 11-\mathrm{S} 21-\mathrm{Ag} 3$ & $106.1(2)$ \\
\hline $\mathrm{C} 11-\mathrm{S} 21-\mathrm{Ag} 2$ & $100.6(2)$ \\
\hline $\mathrm{Ag} 3-\mathrm{S} 21-\mathrm{Ag} 2$ & $83.35(6)$ \\
\hline $\mathrm{C} 11-\mathrm{N} 11-\mathrm{S} 11$ & $110.0(5)$ \\
\hline $\mathrm{C} 11-\mathrm{N} 11-\mathrm{Ag} 1$ & $130.0(4)$ \\
\hline S11-N11-Ag1 & $119.7(3)$ \\
\hline $\mathrm{N} 11-\mathrm{C} 11-\mathrm{C} 21$ & $115.8(6)$ \\
\hline $\mathrm{N} 11-\mathrm{C} 11-\mathrm{S} 21$ & $124.7(5)$ \\
\hline $\mathrm{C} 21-\mathrm{C} 11-\mathrm{S} 21$ & $119.5(5)$ \\
\hline $\mathrm{C} 71-\mathrm{C} 21-\mathrm{C} 31$ & $119.6(7)$ \\
\hline $\mathrm{C} 71-\mathrm{C} 21-\mathrm{C} 11$ & $110.7(6)$ \\
\hline $\mathrm{C} 31-\mathrm{C} 21-\mathrm{C} 11$ & $129.7(6)$ \\
\hline $\mathrm{C} 41-\mathrm{C} 31-\mathrm{C} 21$ & $117.9(7)$ \\
\hline $\mathrm{C} 41-\mathrm{C} 31-\mathrm{H} 31$ & 121.0 \\
\hline $\mathrm{C} 21-\mathrm{C} 31-\mathrm{H} 31$ & 121.0 \\
\hline $\mathrm{C} 31-\mathrm{C} 41-\mathrm{C} 51$ & $122.0(8)$ \\
\hline $\mathrm{C} 31-\mathrm{C} 41-\mathrm{H} 41$ & 119.0 \\
\hline C51-C41-H41 & 119.0 \\
\hline $\mathrm{C} 41-\mathrm{C} 51-\mathrm{C} 61$ & $120.8(8)$ \\
\hline $\mathrm{C} 41-\mathrm{C} 51-\mathrm{H} 51$ & 119.6 \\
\hline $\mathrm{C} 61-\mathrm{C} 51-\mathrm{H} 51$ & 119.6 \\
\hline $\mathrm{C} 71-\mathrm{C} 61-\mathrm{C} 51$ & $117.9(8)$ \\
\hline $\mathrm{C} 71-\mathrm{C} 61-\mathrm{H} 61$ & 121.1 \\
\hline $\mathrm{C} 51-\mathrm{C} 61-\mathrm{H} 61$ & 121.1 \\
\hline $\mathrm{C} 61-\mathrm{C} 71-\mathrm{C} 21$ & $121.7(6)$ \\
\hline C61-C71-S11 & $130.4(6)$ \\
\hline $\mathrm{C} 21-\mathrm{C} 71-\mathrm{S} 11$ & $107.9(5)$ \\
\hline $\mathrm{O} 12-\mathrm{S} 12-\mathrm{O} 22$ & $117.9(4)$ \\
\hline $\mathrm{O} 12-\mathrm{S} 12-\mathrm{N} 12$ & $109.1(3)$ \\
\hline $\mathrm{O} 22-\mathrm{S} 12-\mathrm{N} 12$ & $108.9(3)$ \\
\hline $\mathrm{O} 12-\mathrm{S} 12-\mathrm{C} 72$ & $111.5(4)$ \\
\hline $\mathrm{O} 22-\mathrm{S} 12-\mathrm{C} 72$ & $111.7(3)$ \\
\hline $\mathrm{N} 12-\mathrm{S} 12-\mathrm{C} 72$ & $95.3(3)$ \\
\hline $\mathrm{C} 12-\mathrm{S} 22-\mathrm{Ag} 4$ & $108.8(2)$ \\
\hline $\mathrm{C} 12-\mathrm{S} 22-\mathrm{Ag} 1$ & $100.2(2)$ \\
\hline $\mathrm{Ag} 4-\mathrm{S} 22-\mathrm{Ag} 1$ & $83.95(6)$ \\
\hline $\mathrm{C} 12-\mathrm{N} 12-\mathrm{S} 12$ & $110.8(5)$ \\
\hline
\end{tabular}

\begin{tabular}{|c|c|}
\hline $\mathrm{C} 15-\mathrm{N} 15-\mathrm{C} 55$ & $116.2(7)$ \\
\hline $\mathrm{C} 15-\mathrm{N} 15-\mathrm{Ag} 1$ & $119.2(5)$ \\
\hline $\mathrm{C} 55-\mathrm{N} 15-\mathrm{Ag} 1$ & $124.6(6)$ \\
\hline $\mathrm{C} 105-\mathrm{N} 25-\mathrm{C} 65$ & $115.3(7)$ \\
\hline $\mathrm{C} 105-\mathrm{N} 25-\mathrm{Ag} 2^{\mathrm{ii}}$ & $121.8(5)$ \\
\hline $\mathrm{C} 65-\mathrm{N} 25-\mathrm{Ag} 2^{\mathrm{ii}}$ & $122.4(5)$ \\
\hline $\mathrm{N} 15-\mathrm{C} 15-\mathrm{C} 25$ & $122.7(8)$ \\
\hline $\mathrm{N} 15-\mathrm{C} 15-\mathrm{H} 15$ & 118.7 \\
\hline $\mathrm{C} 25-\mathrm{C} 15-\mathrm{H} 15$ & 118.7 \\
\hline $\mathrm{C} 35-\mathrm{C} 25-\mathrm{C} 15$ & $122.4(9)$ \\
\hline $\mathrm{C} 35-\mathrm{C} 25-\mathrm{H} 25$ & 118.8 \\
\hline $\mathrm{C} 15-\mathrm{C} 25-\mathrm{H} 25$ & 118.8 \\
\hline $\mathrm{C} 45-\mathrm{C} 35-\mathrm{C} 25$ & $114.7(8)$ \\
\hline $\mathrm{C} 45-\mathrm{C} 35-\mathrm{C} 115$ & $121.9(10)$ \\
\hline $\mathrm{C} 25-\mathrm{C} 35-\mathrm{C} 115$ & $123.4(10)$ \\
\hline $\mathrm{C} 35-\mathrm{C} 45-\mathrm{C} 55$ & $121.0(9)$ \\
\hline $\mathrm{C} 35-\mathrm{C} 45-\mathrm{H} 45$ & 119.5 \\
\hline $\mathrm{C} 55-\mathrm{C} 45-\mathrm{H} 45$ & 119.5 \\
\hline $\mathrm{N} 15-\mathrm{C} 55-\mathrm{C} 45$ & $123.0(9)$ \\
\hline $\mathrm{N} 15-\mathrm{C} 55-\mathrm{H} 55$ & 118.5 \\
\hline $\mathrm{C} 45-\mathrm{C} 55-\mathrm{H} 55$ & 118.5 \\
\hline $\mathrm{N} 25-\mathrm{C} 65-\mathrm{C} 75$ & $123.0(9)$ \\
\hline $\mathrm{N} 25-\mathrm{C} 65-\mathrm{H} 65$ & 118.5 \\
\hline $\mathrm{C} 75-\mathrm{C} 65-\mathrm{H} 65$ & 118.5 \\
\hline $\mathrm{C} 85-\mathrm{C} 75-\mathrm{C} 65$ & $121.7(9)$ \\
\hline $\mathrm{C} 85-\mathrm{C} 75-\mathrm{H} 75$ & 119.2 \\
\hline $\mathrm{C} 65-\mathrm{C} 75-\mathrm{H} 75$ & 119.2 \\
\hline $\mathrm{C} 75-\mathrm{C} 85-\mathrm{C} 95$ & $113.8(7)$ \\
\hline $\mathrm{C} 75-\mathrm{C} 85-\mathrm{C} 135$ & $119.6(12)$ \\
\hline $\mathrm{C} 95-\mathrm{C} 85-\mathrm{C} 135$ & $126.6(12)$ \\
\hline $\mathrm{C} 105-\mathrm{C} 95-\mathrm{C} 85$ & $122.9(9)$ \\
\hline $\mathrm{C} 105-\mathrm{C} 95-\mathrm{H} 95$ & 118.6 \\
\hline C $85-\mathrm{C} 95-\mathrm{H} 95$ & 118.6 \\
\hline $\mathrm{N} 25-\mathrm{C} 105-\mathrm{C} 95$ & $123.1(8)$ \\
\hline $\mathrm{N} 25-\mathrm{C} 105-\mathrm{H} 105$ & 118.4 \\
\hline C95-C105-H105 & 118.4 \\
\hline $\mathrm{C} 125-\mathrm{C} 115-\mathrm{C} 35$ & $115.0(8)$ \\
\hline $\mathrm{C} 125-\mathrm{C} 115-\mathrm{H} 11 \mathrm{~A}$ & 108.5 \\
\hline $\mathrm{C} 35-\mathrm{C} 115-\mathrm{H} 11 \mathrm{~A}$ & 108.5 \\
\hline $\mathrm{C} 125-\mathrm{C} 115-\mathrm{H} 11 \mathrm{~B}$ & 108.5 \\
\hline $\mathrm{C} 35-\mathrm{C} 115-\mathrm{H} 11 \mathrm{~B}$ & 108.5 \\
\hline $\mathrm{H} 11 \mathrm{~A}-\mathrm{C} 115-\mathrm{H} 11 \mathrm{~B}$ & 107.5 \\
\hline $\mathrm{C} 115-\mathrm{C} 125-\mathrm{C} 135$ & $124.1(9)$ \\
\hline $\mathrm{C} 115-\mathrm{C} 125-\mathrm{H} 12 \mathrm{~A}$ & 106.3 \\
\hline $\mathrm{C} 135-\mathrm{C} 125-\mathrm{H} 12 \mathrm{~A}$ & 106.3 \\
\hline $\mathrm{C} 115-\mathrm{C} 125-\mathrm{H} 12 \mathrm{~B}$ & 106.3 \\
\hline $\mathrm{C} 135-\mathrm{C} 125-\mathrm{H} 12 \mathrm{~B}$ & 106.3 \\
\hline $\mathrm{H} 12 \mathrm{~A}-\mathrm{C} 125-\mathrm{H} 12 \mathrm{~B}$ & 106.4 \\
\hline
\end{tabular}




$\begin{array}{ll}\mathrm{C} 12-\mathrm{N} 12-\mathrm{Ag} 2 & 129.0(4) \\ \mathrm{S} 12-\mathrm{N} 12-\mathrm{Ag} 2 & 118.8(3) \\ \mathrm{N} 12-\mathrm{C} 12-\mathrm{C} 22 & 115.1(6) \\ \mathrm{N} 12-\mathrm{C} 12-\mathrm{S} 22 & 125.0(5) \\ \mathrm{C} 22-\mathrm{C} 12-\mathrm{S} 22 & 119.9(5) \\ \mathrm{C} 72-\mathrm{C} 22-\mathrm{C} 32 & 120.3(7) \\ \mathrm{C} 72-\mathrm{C} 22-\mathrm{C} 12 & 110.8(6) \\ \mathrm{C} 32-\mathrm{C} 22-\mathrm{C} 12 & 128.9(7) \\ \mathrm{C} 22-\mathrm{C} 32-\mathrm{C} 42 & 117.3(8) \\ \mathrm{C} 22-\mathrm{C} 32-\mathrm{H} 32 & 121.3 \\ \mathrm{C} 42-\mathrm{C} 32-\mathrm{H} 32 & 121.3 \\ \mathrm{C} 52-\mathrm{C} 42-\mathrm{C} 32 & 120.9(9) \\ \mathrm{C} 52-\mathrm{C} 42-\mathrm{H} 42 & 119.6 \\ \mathrm{C} 32-\mathrm{C} 42-\mathrm{H} 42 & 119.6 \\ \mathrm{C} 42-\mathrm{C} 52-\mathrm{C} 62 & 121.6(8) \\ \mathrm{C} 42-\mathrm{C} 52-\mathrm{H} 52 & 119.2 \\ \mathrm{C} 62-\mathrm{C} 52-\mathrm{H} 52 & 119.2 \\ \mathrm{C} 72-\mathrm{C} 62-\mathrm{C} 52 & 117.0(8) \\ \mathrm{C} 72-\mathrm{C} 62-\mathrm{H} 62 & 121.5 \\ \mathrm{C} 52-\mathrm{C} 62-\mathrm{H} 62 & 121.5 \\ \mathrm{C} 22-\mathrm{C} 72-\mathrm{C} 62 & 122.9(7) \\ \mathrm{C} 22-\mathrm{C} 72-\mathrm{S} 12 & 108.1(5) \\ \mathrm{C} 62-\mathrm{C} 72-\mathrm{S} 12 & 129.1(6) \\ \mathrm{O} 23-\mathrm{S} 13-\mathrm{O} 13 & 117.0(4) \\ \mathrm{O} 23-\mathrm{S} 13-\mathrm{N} 13 & 110.4(4) \\ \mathrm{O} 13-\mathrm{S} 13-\mathrm{N} 13 & 109.4(4) \\ \mathrm{O} 23-\mathrm{S} 13-\mathrm{C} 73 & 110.9(4) \\ \mathrm{O} 13-\mathrm{S} 13-\mathrm{C} 73 & 111.9(4) \\ \mathrm{N} 13-\mathrm{S} 13-\mathrm{C} 73 & 95.0(3) \\ \mathrm{C} 13-\mathrm{S} 23-\mathrm{Ag} 4 & 104.2(2) \\ \mathrm{C} 13-\mathrm{S} 23-\mathrm{Ag} 2 & 110.9(2) \\ \mathrm{Ag} 4-\mathrm{S} 23-\mathrm{Ag} 2 & 69.53(5) \\ \mathrm{C} 13-\mathrm{N} 13-\mathrm{S} 13 & 112.2(5) \\ \mathrm{C} 13-\mathrm{N} 13-\mathrm{Ag} 3 & 123.1(5) \\ \mathrm{S} 13-\mathrm{N} 13-\mathrm{Ag} 3 & 120.6(3) \\ \mathrm{N} 13-\mathrm{C} 13-\mathrm{C} 23 & 113.6(6) \\ \mathrm{N} 13-\mathrm{C} 13-\mathrm{S} 23 & 125.5(5) \\ \mathrm{C} 23-\mathrm{C} 13-\mathrm{S} 23 & 120.9(5) \\ \mathrm{C} 73-\mathrm{C} 23-\mathrm{C} 33 & \\ & \end{array}$

$\mathrm{C} 125-\mathrm{C} 135-\mathrm{C} 85 \quad 119.3(8)$

$\mathrm{C} 125-\mathrm{C} 135-\mathrm{H} 13 \mathrm{~A} \quad 107.5$

$\mathrm{C} 85-\mathrm{C} 135-\mathrm{H} 13 \mathrm{~A} \quad 107.5$

$\mathrm{C} 125-\mathrm{C} 135-\mathrm{H} 13 \mathrm{~B} \quad 107.5$

$\mathrm{C} 85-\mathrm{C} 135-\mathrm{H} 13 \mathrm{~B} \quad 107.5$

$\mathrm{H} 13 \mathrm{~A}-\mathrm{C} 135-\mathrm{H} 13 \mathrm{~B} \quad 107.0$

$\mathrm{O} 1 \mathrm{~A}-\mathrm{S} 1 \mathrm{~A}-\mathrm{C} 1 \mathrm{~A} \quad 109.3(6)$

O1A-S1A-C2A 109.1 (6)

$\mathrm{C} 1 \mathrm{~A}-\mathrm{S} 1 \mathrm{~A}-\mathrm{C} 2 \mathrm{~A} \quad 109.2(12)$

$\mathrm{S} 1 \mathrm{~A}-\mathrm{C} 1 \mathrm{~A}-\mathrm{H} 1 \mathrm{~A} \quad 109.5$

$\mathrm{S} 1 \mathrm{~A}-\mathrm{C} 1 \mathrm{~A}-\mathrm{H} 1 \mathrm{~B} \quad 109.5$

$\mathrm{H} 1 \mathrm{~A}-\mathrm{C} 1 \mathrm{~A}-\mathrm{H} 1 \mathrm{~B} \quad 109.5$

S1A-C1A-H1C $\quad 109.5$

$\mathrm{H} 1 \mathrm{~A}-\mathrm{C} 1 \mathrm{~A}-\mathrm{H} 1 \mathrm{C} \quad 109.5$

$\mathrm{H} 1 \mathrm{~B}-\mathrm{C} 1 \mathrm{~A}-\mathrm{H} 1 \mathrm{C} \quad 109.5$

$\mathrm{S} 1 \mathrm{~A}-\mathrm{C} 2 \mathrm{~A}-\mathrm{H} 2 \mathrm{~A} \quad 109.5$

$\mathrm{S} 1 \mathrm{~A}-\mathrm{C} 2 \mathrm{~A}-\mathrm{H} 2 \mathrm{~B} \quad 109.5$

$\mathrm{H} 2 \mathrm{~A}-\mathrm{C} 2 \mathrm{~A}-\mathrm{H} 2 \mathrm{~B} \quad 109.5$

$\mathrm{S} 1 \mathrm{~A}-\mathrm{C} 2 \mathrm{~A}-\mathrm{H} 2 \mathrm{C} \quad 109.5$

$\mathrm{H} 2 \mathrm{~A}-\mathrm{C} 2 \mathrm{~A}-\mathrm{H} 2 \mathrm{C} \quad 109.5$

$\mathrm{H} 2 \mathrm{~B}-\mathrm{C} 2 \mathrm{~A}-\mathrm{H} 2 \mathrm{C} \quad 109.5$

O1B-S1B-C1B $109.6(6)$

O1B-S1B-C2B 109.3 (7)

C1B-S1B-C2B 109.6 (12)

S1B-C1B-H1D $\quad 109.5$

S1B - C1B-H1E $\quad 109.5$

H1D $-\mathrm{C} 1 \mathrm{~B}-\mathrm{H} 1 \mathrm{E}$

S1B-C1B-H1F $\quad 109.5$

H1D-C1B-H1F $\quad 109.5$

$\mathrm{H} 1 \mathrm{E}-\mathrm{C} 1 \mathrm{~B}-\mathrm{H} 1 \mathrm{~F} \quad 109.5$

$\mathrm{S} 1 \mathrm{~B}-\mathrm{C} 2 \mathrm{~B}-\mathrm{H} 2 \mathrm{D} \quad 109.5$

$\mathrm{S} 1 \mathrm{~B}-\mathrm{C} 2 \mathrm{~B}-\mathrm{H} 2 \mathrm{E} \quad 109.5$

$\mathrm{H} 2 \mathrm{D}-\mathrm{C} 2 \mathrm{~B}-\mathrm{H} 2 \mathrm{E} \quad 109.5$

$\mathrm{S} 1 \mathrm{~B}-\mathrm{C} 2 \mathrm{~B}-\mathrm{H} 2 \mathrm{~F} \quad 109.5$

$\mathrm{H} 2 \mathrm{D}-\mathrm{C} 2 \mathrm{~B}-\mathrm{H} 2 \mathrm{~F} \quad 109.5$

$\mathrm{H} 2 \mathrm{E}-\mathrm{C} 2 \mathrm{~B}-\mathrm{H} 2 \mathrm{~F} \quad 109.5$

Ag4-O1W-H1WA $158(9)$

Ag4-O1W-H1WB 97 (9)

H1WA-O1W-H1WB 103.4 (15)

Symmetry codes: (i) $x+1, y, z-1$; (ii) $x-1, y, z+1$.

Hydrogen-bond geometry $\left(A,{ }^{\circ}\right)$

\begin{tabular}{lllll}
\hline$D-\mathrm{H} \cdots A$ & $D-\mathrm{H}$ & $\mathrm{H} \cdots A$ & $D \cdots A$ & $D-\mathrm{H} \cdots A$ \\
\hline $\mathrm{O} 1 W-\mathrm{H} 1 W B \cdots \mathrm{O} 14$ & $0.95(10)$ & $2.59(11)$ & $3.425(18)$ & $147(9)$ \\
$\mathrm{O} 1 W-\mathrm{H} 1 W B \cdots \mathrm{O} 24$ & $0.95(10)$ & $2.59(8)$ & $3.072(18)$ & $112(8)$ \\
$\mathrm{O} 1 W-\mathrm{H} 1 W A \cdots \mathrm{O} 1 A^{\mathrm{iii}}$ & $0.96(9)$ & $2.05(18)$ & $2.65(2)$ & $119(12)$
\end{tabular}


supporting information

$\begin{array}{lllll}\mathrm{C} 125-\mathrm{H} 12 B \cdots \mathrm{O} 1 W^{\mathrm{iii}} & 0.97 & 2.53 & 3.369(17) & 144 \\ \mathrm{C} 44-\mathrm{H} 44 \cdots \mathrm{O} 11^{\mathrm{iv}} & 0.93 & 2.52 & 3.260(13) & 137 \\ \mathrm{C} 53-\mathrm{H} 53 \cdots \mathrm{S} 21^{\mathrm{v}} & 0.93 & 2.86 & 3.572(9) & 134 \\ \mathrm{C} 75-\mathrm{H} 75 \cdots \mathrm{O} 24^{\mathrm{vi}} & 0.93 & 2.41 & 3.284(16) & 158 \\ \mathrm{C} 105-\mathrm{H} 105 \cdots \mathrm{S} 23^{\mathrm{ii}} & 0.93 & 2.82 & 3.508(9) & 132\end{array}$

Symmetry codes: (ii) $x-1, y, z+1$; (iii) $-x+1,-y+1,-z+1$; (iv) $-x+1,-y,-z+1$; (v) $-x+2,-y,-z$; (vi) $x, y, z+1$. 